\title{
Experimental Studies on essential cause for the sexual difference of the thyroid function
}

\author{
By
}

\author{
Yasushi INOUE \\ From the Department of Obstetrics and Gynecology, Kobe Medical College \\ (Director : Prof. Yasuo Ueda)
}

It has been clincically known that thyroid diseases are seen more frequently in the female than in the male. However, the sexual differences are not as yet fully explained. For this purpose, effects of castration on the thyroid function and effects of gonadal steroid hormones on the thyroid function of the castrate mature rats of both sexes were investigated. For determination of the thyroid function, radioactive iodine $\mathrm{I}^{131}$ was used and remarkable findings were obtained.

The results are summarized as follows:

1) Effects of castration on the thyroid function were manifested by hypofunction, usually, 14 days in the female and 42 days in the male, after castration, and greater changes were found in females than in males, and the effects were persisted even 2 months after the castration. It may be concluded that those greater changes in females without distinction to post-operative period had apparently indicated the fact that there are substantial differences of the thyroid function between male and females.

2) It is the matter of course that sexual differences should be looked for in the gonads. But, for the explanation of this mechanism, 3 kinds of steroid hormones; estradiol benzoate, progesterone, and testosterone propionate were administered to the castrated mature rats and these effects on the thyroid function were examined. Marked differences have been found to exist between two sexes.

(1) Estrogen has an accelerating effects on the thyroid uptake of $\mathrm{I}^{131}$ for the female, and on the release of thyroid hormone in the blood of male rats. This diverse response against estrogen is considered to be attributable to the difference in the affinity of the thyroid to estrogen.

(2) When progesterone is injected to the castrated female rats, no changes were found, and in the male, decreased thyroid uptake of $\mathrm{I}^{131}$ was found 14 days, and no obvious changes occurred 2 months after castration.

(3) Androgen has no constant effects on the thyroid of the castrated both sexes.

(4) By the fact that estrogen has coherent effects on the thyroid while androgen causes no change, it can be assumed that the sexual differences are chiefly attributable to estrogen.

(5) The results of steroid hormones injection indicated that in the female thyroid is closely related with the gonad, while the thyroid in the male is not under this control.

(6) Estrogen has an accelerating effects on the female thyroid uptake of $\mathrm{I}^{132}$ irrespective of postoperative periods, suggests the reason for the more frequent occurrence of thyroid diseases in the female.

3) In order to explain the mechanism in which estrogen is the primary fractor on the sexual differences of the thyroid, estrogen was administered to the hypophysectomized female rats and its effect was investigated. Thyroid uptake of $\mathrm{I}^{131}$ showed remarkable increase in comparison with the control groups. By this fact, it can be noted that the estrogen has a direct effects on the thyroid. 


\title{
性差よりみた甲状腺機能の本態に関する実験的研究
}

\author{
神戸医科大学産婦人科学教室（主任 植田安雄教授）
}

井上康

目次

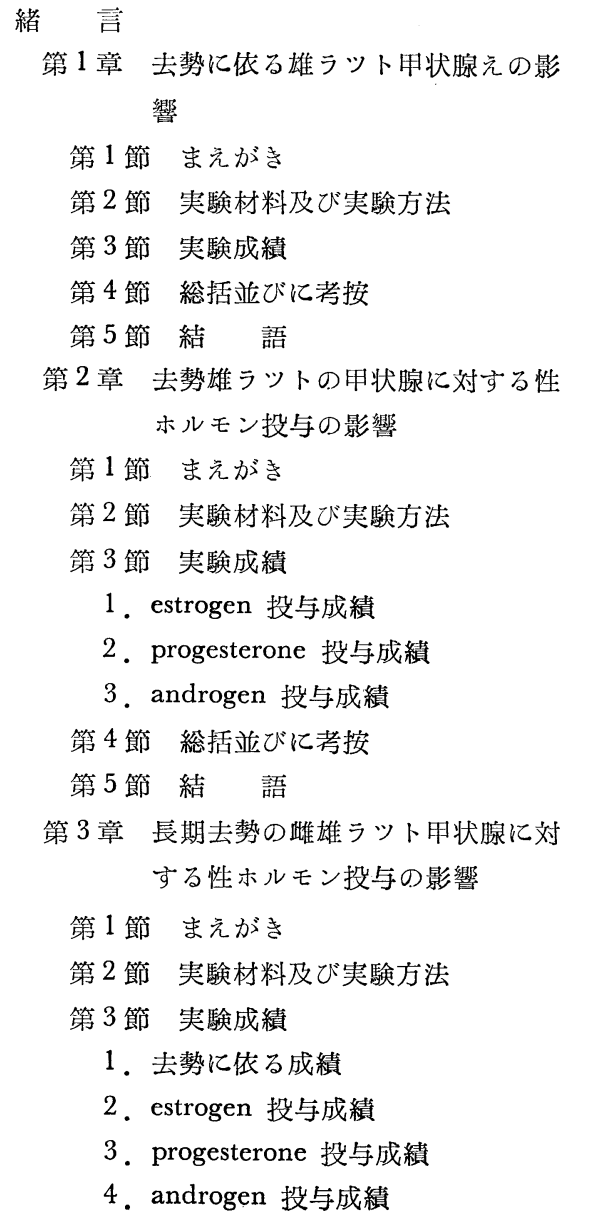

緒言

去势に依る雄ラツト甲状腺えの影

$$
\text { ホルモン投与の影響 }
$$

節 まえがき

第 2 節 実験材料及び実験方法

与成續

2 . progesterone 投与成績

総括並びに考按

する性ホルモン投与の影響

\section{緒}

第 4 節 総括並びに考按

第 5 節 結 語

第 4 章 去勢ラツトに性ホルモン投与時の 甲状腺に対する T S Hの影響並び に下垂体剔除 ラットに estrogen 投与時の甲状腺機能

第 1 節 まえがき

第 2 節 実験材料及び実験方法

第 3 節 実験成績

第 1 項 去勢雄ラツトに性ホルモン前 処置後 $\mathrm{T} \mathrm{S} \mathrm{H}$ 投与成績

1. 去勢ラットに T S H投与成績

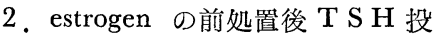
与成績

3 . estrogen-progesterone $の$ 前処 置後 T S H投与成績

4. androgen の前処置後 $\mathrm{T} \mathrm{S} \mathrm{H}$ 投 与成績

第 2 項 下垂体剔除雌ラツトに estrogen 投与成績

1. 下垂体剔除成熟雌ラットに estrogen 投与成績

2 .下垂体剔除幼若雌ラットに estrogen 投与成續

第 4 節 総括並びに考按

第 5 節 結 語 全章の総括並びに結論

\section{言}

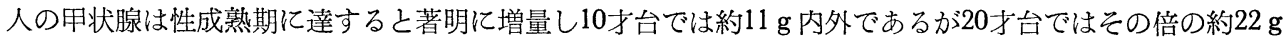
に達し，滤胞の大きさむ又思春期に著しく拡大する．臨床的にも甲状腺は思春期前には男女略々同じ重量で あるが，性成熟期に達すると共に女性の甲状腺重量は男性のそれに倍加し，甲状腺疾患が女性に多発する。 而屯各種の甲状腺疾患が思春期，妊娠，分娩，更年期等卵巣機能の変換期飞好発することは古くから知られ ている，乙れらの事実よりみれば女性性腺之甲状腺との間には密接な関連性があり，又人の甲状腺に関する 限り，その生理，病理に於て相当の性差のあることは疑いのない事実であるが，その依つて来たる原因に就 
いての知見は甚だそしい，又此の問題の解決の基礎となるべき動物実験の成績も極邓てそしく，今日，尚一 定の結論を得ていない，そてで私は甲状腺機能の性差の本態を究明する目的で，雌雄成熟ラットを手術的に 去勢し，その去挘による甲状腺機能えの影響，並びにての際性ホルモンを投与した時の甲状腺機能を放射性 沃度 $I^{131}$ を用いて比較検討した。

\section{第 1 章 去勢に依る雄ラット甲状腺えの影響}

\section{第 1 節 まえがき}

雌性動物を去勢した場合の甲状腺所見に就いては詳細に研究されており，教室の山口 $(1957)^{1)}$ は成熟雌ラ ットを去勢すると，既に14日以後に於て甲状腺 $\mathrm{I}^{131}$ 摄取率は明らかな減少を認めるが，血清 $\mathrm{I}^{131}$ の転換率は 21日以後漸次恢復することを実証している。然し乍ら雄性動物を去勢した際に起る甲状腺所罟に就いて検討 した成績は少い. 而も甲状腺の形態学的所見に基づく研究成績も放射性沃度を追跡子とした実験成績も未だ 一定の結論を得ていない，そこで私は成熟雄ラットを去勢し，去勢後の甲状腺機能の変化を放射性沃度 $\mathrm{I}^{131}$ を用いて検查し，併せて甲状腺の組織学的研究並びに Radioautograph 亿依る検討を加えた。

\section{第 2 節 実験材料及び実験方法}

実験動物には体重120１50 g の C 系成熟雄ラットを用い，飼料として実験に供する 3 週間前より実験の全 期間中一定量のオリエンタル 固形飼料（MC 5$)(1 \mathrm{~g}$ 中沃度含有量 $2.3 \mu \mathrm{g}$ ) と充分な水を与元, 実験は季節 的影響の少い春秋期に行つた。尚その都度同一条件で飼育した非去勢ラットを対照として用いた。 去勢手術 は腹側から行い，睪丸を菼膜から㓥脱して後に剔出した，手術侵襲による甲状腺元の影響を知るため同一条 件で飼育したラットを屠殺24時間前に粹丸を莢膜から露出し，再び元に還納処置したものを偽手術群とし た. tracer として I ${ }^{131}$ の $20 . / \mathrm{c}$ を皮下注射し，注射後 24 時間目に ether 麻酔の下に開腹後，横隔膜下より 心藏穿刺により採血致死せしめ両側甲状腺を剔出し，先づその新鮮重量を torsion balance で科量した。 甲状腺左葉は $2 \mathrm{~N} \mathrm{NaOH} 10 \mathrm{cc}$ 中に溶解せしめ，一方右葉は組織学的検索並びに後述する Radioautograph 用に供した.

1) 甲状腺 $\mathrm{I}^{131}$ 掑取率の測定

山口 $(1957)^{1)}$ の記載せる法に従い, 甲状腺左葉を $2 \mathrm{NNaOH} 10 \mathrm{cc}$ 中で重湯照上にて加熱し完全溶解せし わ, その $1 \mathrm{cc}$ を正確に直径 $2.8 \mathrm{~cm}$ の放射能測定四に入れ, 赤外線電球にて乾固後神戸工業製 Geiger-Müllêr の計数器で $\beta$ 線を測定し，その計測值を 2 倍して両側甲状腺放射能值と見做し，乙れと基準液との百分率を 以つて $\mathrm{I}^{131}$ 摂取率とした。

2) 血清 $\mathrm{I}^{131}$ の蛋白結合沃度 (PBI と略す) 転換率の測定

心藏穿刺にて得た血液を山口 $(1957)^{1)}$ の記載せる法により処理し，血清有機 $\mathrm{I}^{131}$ と血清全 $\mathrm{I}^{131}$ との計

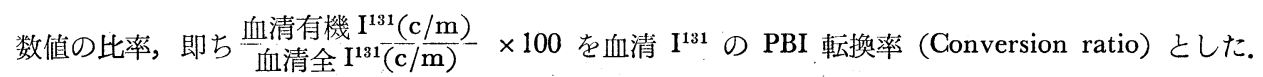

3) 組織学的検索

剔出甲状腺右葉を Carnoy 液で固定し, paraffin 包埋後, haematoxylin \& eosin 染色を施し組織学的検 索に供した。

4) 甲状腺の Radioautograph

山口 $(1957)^{1)}$ の行つた所謂 stripping emulsion method $^{2)}$ を用いた.

\section{第 3 節 実験成績}

偽手術群，去勢後 7 日，14日，21日，28日，42日，60日に於ける各実験群の計測平均值は第 1 表に示す如 くである.

1. 甲状腺 $\mathbf{1}^{131}$ 撖取率 (第 1 表, 第 1 図)

偽手術群及び去勢後28日迄は刘照群との間に大差なく，窑乃僅かであるが増加の傾向を示す。去勢後42日 並びに60日では刘照郡に比して $\mathrm{I}^{131}$ 掑取率は却つて減少するが有意の変化はない。 
第 1 表 去勢後各時期の計測平均值

\begin{tabular}{|c|c|c|c|c|c|c|}
\hline & \multirow{2}{*}{$\begin{array}{l}\text { 動 } \\
\text { 物 } \\
\text { 数 }\end{array}$} & \multirow[b]{2}{*}{ 終体重 } & \multicolumn{2}{|c|}{ 甲 } & 腺 & 血 \\
\hline & & & 重量（mg） & $\begin{array}{l}\text { 体重 } 100 \mathrm{~g} \text { 当り } \\
\text { の重量 }(\mathrm{mg})\end{array}$ & $\mathrm{I}^{131}$ 摂取率 $(\%)$ & $\begin{array}{c}\text { P B I 転換率 } \\
(\%)\end{array}$ \\
\hline 照 & 5 & 116.6 & 10.4 & $8.21 \pm 0.80$ & $11.62 \pm 1.32$ & $50.28 \pm 3.82$ \\
\hline 偽 手 術 & 5 & 117.6 & 10.0 & $8.50 \pm 1.26$ & $11.48 \pm 2.13$ & $57.37 \pm 3.98$ \\
\hline 去勢後 7日 & 6 & 132.6 & 11.7 & $8.82 \pm 1.01$ & $15.57 \pm 0.95$ & $58.88 \pm 0.92$ \\
\hline 去勢後14日 & 7 & 122.7 & 11.3 & $9.20 \pm 1.69$ & $11.76 \pm 1.48$ & $35.33 \pm 3.85$ \\
\hline 去勢後21日 & 6 & 146.6 & 11.7 & $8.66 \pm 1.90$ & $14.54 \pm 2.2 \varepsilon$ & $62.62 \pm 4.76$ \\
\hline 去勢後28日 & 5 & 148.0 & 11.7 & $7.93 \pm 0.32$ & $13.88 \pm 0.69$ & $71.40 \pm 3.13^{*}$ \\
\hline 去勢後42日 & 5 & 163.8 & 13.0 & $7.93 \pm 1.40$ & $7.09 \pm 1.71$ & $54.00 \pm 2.89$ \\
\hline 去勢後60日 & 5 & 168.0 & 13.8 & $8.21 \pm 1.15$ & $10.96 \pm 0.34$ & $51.40 \pm 1.43$ \\
\hline
\end{tabular}

有意差は各計測平均值を対照のそれと比較したものである ${ }^{*} \mathrm{P}<0.05$

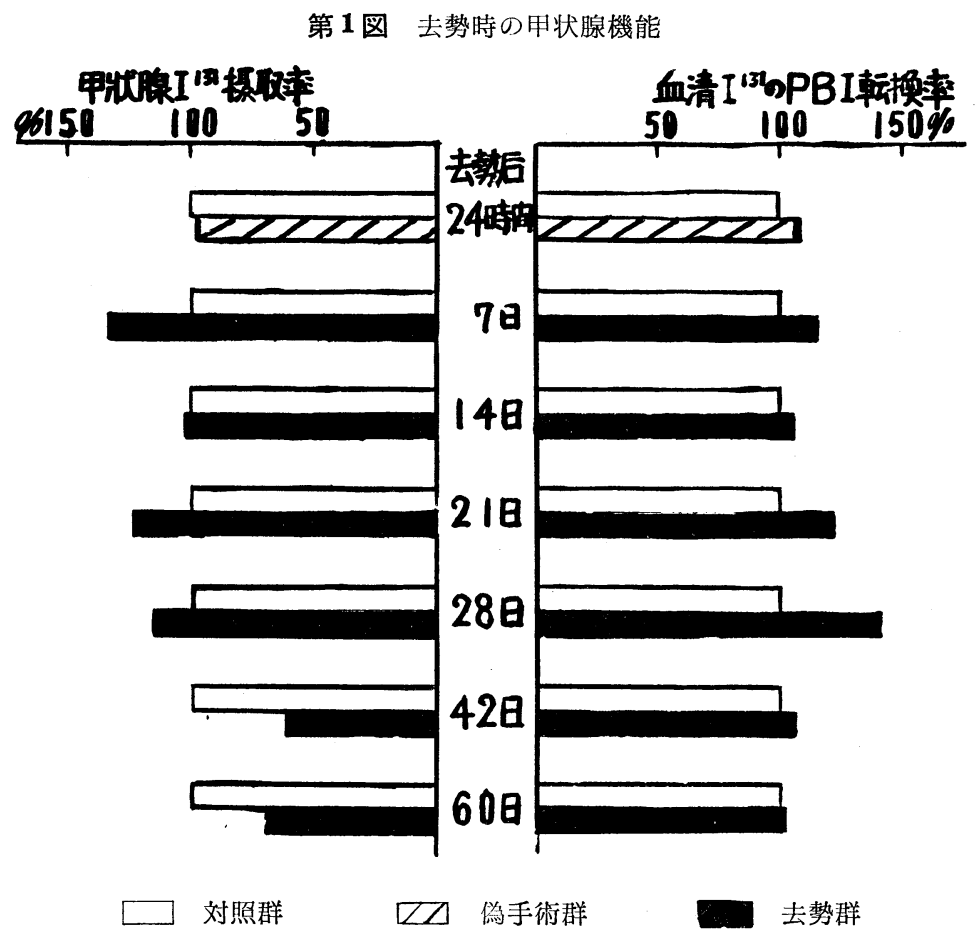

2. 血淸の $\mathrm{I}^{131} \mathrm{PBI}$ 転換率（第 1 表，第 1 図）

偽手術群並びに去勢群では一般に対照群に比して稍々増加の傾向を示し，特に去勢後28日群では対照群と の間に有意の増加を認めた。

3. 甲状腺重量（第 1 表）

甲状腺重量は去勢による特定の変化は認められない。

4.甲状腺の組織学的所見（附図(1)及び(3)）

去勢後 7 日，14日，21日，28日では去勢群は対照群に比し殆んど差異なく，去勢後42日及び60日では大型 滤胞は増加し，小型滤胞は減少の傾向を示し，濾胞上皮は概して扁平となり，コロイドを充満せる滤胞が増 
加する．上皮細胞は所謂暗調細胞が増加し，核は原形質の基底部に偏して位する。即ち無処置対照群に比し

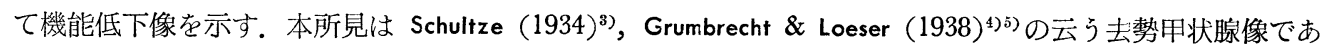
る.

5. Radioautograph に依る実験成績（附図(2)及び(4)

甲状腚の Radioautograph の成績は概ね各甲状腺の $I^{131}$ 攝取率の成績之一致した。即ち去势後28日迄の あのでは濾胞内 $I^{131}$ の沈着は対照群に比べて殆んど差異なく，Autograph 像は概权相似た所見を呈したが， 去勢後28日以後では対照群に比して濾胞内の $I^{131}$ 沈着は少なく，Autograph 像は対照に比へ淡い所見を得 た.

\section{第 4 節 総括並びに考按}

雄性動物を去勢した時の甲状腺所見に就いて研究した業績をみると，組織学的所見に基づく研究業績も， 又放射性沃度を追跡子とした実験成績も未だ一定の結論を得ていない. 先づ甲状腺重量に就いて Anderse \& Kennedy (1933) ${ }^{6)}$ は成熟以前に去勢したラットでは去勢後28日及び42日を経ても重量は変化せず，成熟 ラットでは去势後 3 週乃至 8 週後に重量の減少傾向を認めたと述へ，Hatai (1915) ) は生後22日に去勢した ラットでは去勢後 3〜 5 カ月で重量の減少を, 成熟ラットで屯去勢後軽度の重量減少を認めたとし, MercierParot $(1952)^{8)}$ は幼若ラットの甲状腺重量は去势後40日で対照に比し $7 \%$ \%増加を， Livingston $(1916)^{9)}$ は 雄家鬼では去勢後甲状腺重量の軽度の減少を，雌家鬼では変化しないとし，尚重量は年令，体重去勢期間に 依つて多少の変動を受けると報じ，Breneman \& Mason (1951) ${ }^{10}$ 恃生後 5 日目の雛を去勢し，去勢後120日で 甲状腺重量は減少を来たすとし，斎藤（1930） ${ }^{11}$ は雄家兔を用い去勢後 1 週では重量の増加を，4 週後では 減少傾向を認內たと述へている，汃如く雄動物の性腺を剔除すると，一般に甲状腺重量は減少するもの の如くであるが，未だ研究者により一致した成績は得られていない，乙の原因は主に動物の種類，去勢時期， 去勢期間等が沤々であるためと解せられる，私の実験成績では去勢によつて甲状腺重量は対照に比し明らか な変化を認め得なかつた。

次に去勢に依る甲状腺の組織学的変化に就いてみると，Andersen \& Kennedy (1933) ${ }^{6)}$ は雄ラットの甲状 腺組織像は去勢手術が成熟前或は成熟後に行われるかに依り明らかな差異があると述へ，生後21日に去勢し たものは去势後 28 日目では対照との間に大差なく，80日目では明らかに機能低下像を認めたとし，又生後 80 日で去勢したあのは去勢後 1 週間では対照と変化なく，8週間目に於て最も著明な機能低下像を得たと報告 している. Kippen \& Loeb $(1936)^{12)}$ は成熟雌雄モルモットを去勢した処， 1 週間後には機能克進像を呈す るが，その後速か正常像に復するとし，Chouke (1930) ${ }^{13)}$ はモルモットで去勢後 1 力月以内では影響がな いとし，Crepax (1951a) ${ }^{14)}$ はラットで去勢後10日以内は光進像を，10〜40日では対照との間侸差なく， 40－90日では機能低下像をみたと述へている. Mercier-Parot \& Tachmann-Duplessis $(1951)^{15)}$ は去勢ラットの 甲状腺はその細胞高の減少とコロイドの増加から機能低下を，Aron \& Marescaux (1952) ${ }^{16)}$ は反対に去勢モ ルモットの甲状腺は機能六進像を示す場合があると報告している。最近 Ohida (1954) ${ }^{17}$ は雔雄マウスで甲 状腺の組織学的計測值を以つて検討し，去勢直後では機能低下を来たすが生後50日のマウスでは去勢後30日 で, 生後100日のあのでは去勢後40日で夫々正常像に復するとし，尚雌雄による差異は全く認められなかつ たと報告している，以上従来の研究業績からみて去勢に依る甲状腺の組織変化に就いても未だ定説がない。 私の実験成績では去勢に依る甲状腺の組織所見は去勢後28日目迄は対照群と殆んぞ差異なく，42日以後では 大型滤胞の増加，小型滤胞の娍少，滤胞上皮の扁平化，コロイドの充満等正常群に比し機能低下像を認奷 た。即ち去勢に依つて雄ラット甲状腺が機能低下を来たすのは Crepax (1951a) ${ }^{14)}$ の云う如く40日以後であ ると考えられる。

次に放射性沃度 $\mathrm{I}^{131}$ を以つて雄性動物の去勢後の甲状腺機能を検討した成績は極めて少いが，Kochakian \& Evans (1956) ${ }^{18)}$ は $\mathrm{I}^{131}$ 摂取率の所見加ら去勢に依つて雄ラットの甲状腺は変化を受けないと報じてい る。私は $\mathrm{I}^{131}$ を以つて甲状腺機能を検索した処， $\mathrm{I}^{131}$ 摄取率は去勢後28日迄は殆んど正常群と差異なく， 42 日以後では $\mathrm{I}^{131}$ 㠌取率は低下する傾向を認めた。血清 $I^{131}$ のPBI 転換率は去勢後28日群に於てのみ明 
らかな増加を来たした以外，他は対照群との間に大差は認められない．即ち $\mathrm{I}^{131}$ 摂取率の成績からみても上 述の組織学的所見の成績と同様に去勢後42日以後に於て甲状腺機能が低下することが明らかとなつた。一方 又，甲状腺の Radioautograph の成績は甲状腺 $\mathrm{I}^{131}$ 摂取率の成績とよく一致した。

さて教室の山口 $(1957)^{1)}$ は成熟雌ラットを用い甲状腺 $\mathrm{I}^{131}$ 摄取率は去勢14日以後明らか亿低下し，ての 低下は 3 週後，4 週後，5 週後に於ても依然として持続するととを実証し，一方血清 $\mathbf{I}^{131}$.の PBI 転換率は 3 週以後漸次恢復するととからみて, 甲状腺のホルモン分泌能は 3 週以後正常に復するとし, 即ち沃度代謝 は低い乍らも一つの新らしい平衡を獲得するに至つたもの之解釈している，乙れと私の得た実験成績と比較 考察してみる之，去勢依る甲状腺えの影響は雙雄ラットに依つて著しい差異のあるととは明らかである。 即ち去勢による甲状腺えの影響は雄に比し雌の方が迅速に現われ，且著明であると解せられる。

\section{第 5 節 結 語}

成熟雄ラットの去勢後 7，14，21，28，42，60日の甲状腺機能を $\mathrm{I}^{131}$ 在以つて検索し，併せて甲状腺の組 織学的検索並びに Radioautograph に依る検討を加え，次の如き結果を得た。

1）甲状腺 $\mathbf{I}^{131}$ 掑取率は去势後28日迄は刘照群と殆んど龵異なく，42日以後では低下する傾向を認めた。

2) 血清 $\mathrm{I}^{131}$ の PBI 転換率は去勢後28日群に於てのみ明らかな増加を認めた以外，対照群との間に大差 は認められない。

3）甲状腺重量は去勢に依り特定の影響は認められない.

4) 甲状腺の組織学的所見は去勢後 7 日，14日，21日，28日では刘照群と差異なく，42日以後では対照群 飞比して機能低下像を認め, 所謂去勢甲状腺像を得た。

5) 甲状腺の Radioautograph の成績は概ね各甲状腺の $\mathrm{I}^{131}$ 掑取率の成績と一致をみた. 即ち去後42日 以降のものでは対照群に比して滤胞内の $I^{131}$ の沈着が少なく，従つて Autograph 像は対照群に比へ淡い像 を呈した。

6) 以上から去勢によつて雄ラットの甲状腺が機能低下を来たすのは42日以後であると解せられる.

\section{第 2 章＼cjkstart去勢雄ラットの甲状腺に対する性ホルン投与の影響}

\section{第 1 節 まえがき}

第 1 章に於て成熟雄ラットを去勢し，去勢後42日を経ると甲状腺機能力゙低下する㖽向にあるととを実験的 に証明し，尚去勢によつて起る甲状腺機能の変化は雌雄ラットに依つて著しい差異のあることを知り得たが， 此の反応差の依つて来たる原因は当然性腺の相違に求わなくてはならない，従つてその機序を解明する為に は夫々の性腺より分泌されるホルモンと甲状腺との関係を検討する必要がある。扔て教室の山口 $(1957)^{1)}$ は去勢後14日を経た雌ラットに性ホルモンを投与した時の甲状腺機能に就いて既に詳細な研究成績を報告し ているので，私は去勢後14日を経た雄ラットに性ホルモン 3 種 (estrogen, progesterone 及び androgen)を 投与した時の甲状腺機能を検討するとととした.

\section{第 2 節 実験材料及び実験方法}

第 1 章で述べたと同様の実験材料及び実験方法を用い，去勢後 14 日を経たものに estradiol benzoate， progesterone, testosterone propionate を夫々第 2 表に示す如く投与し, 更に第 1 章と同様に処理し検索を 行つた。尚，各性ホルモンは精製胡麻油 $0.5 \mathrm{cc}$ 中に夫々の量を含有する如く調製しラットの背部に皮下注射 した. 対照として精製胡麻油 $0.5 \mathrm{cc}$ を皮下注射した去勢ラットを用いた。

\section{第 3 節 実験成綪}

各種性ホルモンを投与した時の各実験成績の平均值は第 2 表に示す如くである.

\section{1. estrogen 投与或綪}

1) 甲状腺 $\mathrm{I}^{131}$ 摂取率（第 2 表，第 2 図）

estrogen 全量 $5 \mathrm{mg}$ 投与群では対照群に比し有意の差を以つて增加し $(\mathrm{P}<0.05)$, 全量 $0.5 \mathrm{mg}, 50 \gamma, 5 \gamma$ の estrogen を投与した 3 群では共に対照群に比して有意の変化はない. 
第 2 表 去勢後各種性ホルモン投与時の計測平均值

\begin{tabular}{|c|c|c|c|c|c|c|c|c|c|}
\hline & \multirow{2}{*}{$\begin{array}{l}\text { 投日 } \\
\text { 与数 } \\
\end{array}$} & \multirow{2}{*}{$\begin{array}{c}1 \text { 日 } \\
\text { 投与量 }\end{array}$} & \multirow[b]{2}{*}{ 投与全量 } & \multirow{2}{*}{$\begin{array}{l}\text { 動 } \\
\text { 物 } \\
\text { 数 }\end{array}$} & \multirow{2}{*}{$\begin{array}{l}\text { 終体重 } \\
(\mathrm{g})\end{array}$} & \multicolumn{2}{|r|}{ 甲 } & \multirow{2}{*}{$\begin{array}{l}\text { 腺 } \\
\mathrm{I}^{131} \text { 緅取率 } \\
(\%)\end{array}$} & \multirow{2}{*}{$\begin{array}{c}\text { 血 清 } \\
\text { P B I 転換率 } \\
(\%)\end{array}$} \\
\hline & & & & & & $\begin{array}{l}\text { 重 量 } \\
(\mathrm{mg})\end{array}$ & $\begin{array}{l}\text { 体重100g当り } \\
\text { の重量 (mg) }\end{array}$ & & \\
\hline \multirow{2}{*}{$\begin{array}{l}\text { 正常無処置 } \\
\text { 対照(去勢) }\end{array}$} & 5 & $0.5 \mathrm{cc} \triangle$ & $2.5 \mathrm{cc} \triangle$ & 5 & 122.5 & 12.3 & \multirow{2}{*}{$\begin{array}{r}10.04 \pm 1.71 \\
9.38 \pm 0.90\end{array}$} & $34.91 \pm 2.45$ & \multirow{2}{*}{$\mid \begin{array}{l}47.21 \pm 3.58 \\
53.40 \pm 2.50\end{array}$} \\
\hline & 5 & $0.5 \mathrm{cc} \triangle$ & $2.5 \mathrm{cc} \triangle$ & 4 & 131.2 & 12.3 & & $32.64 \pm 1.28$ & \\
\hline \multirow{4}{*}{$\begin{array}{l}\text { estradiol } \\
\text { benzoate }\end{array}$} & 5 & $1 \mathrm{mg}$ & $5 \mathrm{mg}$ & 4 & 140.0 & 14.0 & $10.00 \pm 1.65$ & $51.86 \pm 2.08^{*}$ & $75.76 \pm 4.89^{*}$ \\
\hline & 5 & $0.1 \mathrm{mg}$ & $0.5 \mathrm{mg}$ & 4 & 125.5 & 12.0 & $9.56 \pm 1.23$ & $44.99 \pm 3.11$ & $67.13 \pm 3.64^{*}$ \\
\hline & 5 & 10 & $50 \gamma$ & 4 & 131.2 & 11.8 & $8.99 \pm 0.30$ & $32.66 \pm 2.11$ & \multirow{2}{*}{$\mid \begin{array}{l}72.68 \pm 3.19^{*} \\
77.41 \pm 4.39 * *\end{array}$} \\
\hline & 5 & $1 \gamma$ & $5 \gamma$ & 4 & 131.7 & 11.3 & $8.58 \pm 1.49$ & $38.63 \pm 2.57$ & \\
\hline \multirow{3}{*}{ progesterone } & 5 & $5 \mathrm{mg}$ & $25 \mathrm{mg}$ & 4 & 115.0 & 11.3 & \multirow{3}{*}{$\begin{array}{l}9.83 \pm 1.22 \\
9.16 \pm 1.90 \\
9.05 \pm 1.02\end{array}$} & $23.40 \pm 1.31^{*}$ & \multirow{3}{*}{$\begin{array}{l}43.33 \pm 3.15 \\
49.70 \pm 2.23 \\
50.94 \pm 1 \cdot 46\end{array}$} \\
\hline & 5 & $0.5 \mathrm{mg}$ & $2.5 \mathrm{mg}$ & 4 & 111.3 & 10.2 & & $22.56 \pm 0.97 *$ & \\
\hline & 5 & $50 \gamma$ & $0.25 \mathrm{mg}$ & 5 & 126.0 & 11.4 & & $21.63 \pm 1.72^{*}$ & \\
\hline \multirow{3}{*}{$\begin{array}{l}\text { testosterone } \\
\text { propionate }\end{array}$} & 5 & $5 \mathrm{mg}$ & $25 \mathrm{mg}$ & 4 & 134.2 & 12.5 & \multirow{3}{*}{$\begin{array}{l}9.31 \pm 0.51 \\
9.30 \pm 0.99 \\
9.02 \pm 1.64\end{array}$} & $38.99 \pm 2.48$ & \multirow{3}{*}{$\mid \begin{array}{l}64.80 \pm 3.94 \\
60.82 \pm 2.00 \\
64.65 \pm 4.53\end{array}$} \\
\hline & 5 & $0.5 \mathrm{mg}$ & $2.5 \mathrm{mg}$ & 4 & 125.2 & 11.3 & & $34.97 \pm 1.98$ & \\
\hline & 5 & 50 & $0.25 \mathrm{mg}$ & 4 & 127.5 & 11.5 & & $40.70 \pm 2.27$ & \\
\hline
\end{tabular}

有意差は各計測平均值を対照のそれと比較したものである

* $\mathrm{P}<0.05 \quad$ ** $\mathrm{P}<0.01 \quad$ 土平均誤差を示与 $\triangle$ 精製胡麻油のみ

第 2 図 去勢後 Estrogen 投与時の甲状腺機能

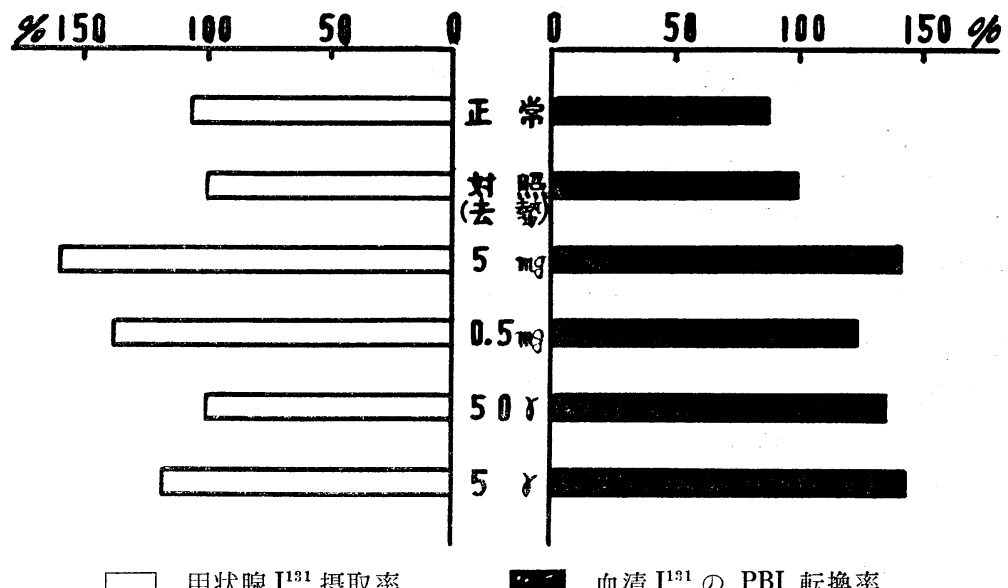

2) 血清 $\mathrm{I}^{131}$ の PBI 転換率（第 2 表，第 2 図）

estrogen を投与した 4 群共に対照群に比して有意の增加を示した（投与全量 $5 \mathrm{mg}, 0.5 \mathrm{mg}, 50 \gamma$

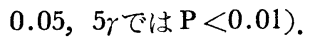

3) 甲状腺重量（第 2 表）

estrogen を投与した 4 群共対照群に比して明らかな変化は認められない。

4) 甲状腺の組織学的所見（附図(D)

estrogen を投与した 4 群共対照群に比して著明な変化は認められないが，一般に滤胞上皮細胞の軽度の肥 大，一部濾胞上皮細胞内には分泌空胞の増加，並びに濾胞間上皮細胞，上皮芽の増加する傾向を認もた。即 
ち対照群に比して組織学的に軽度の機能克進像を示した。

5) Radioautograph 亿依る成績（附図(6)

estrogen 全量 $5 \mathrm{mg}$ 投与群では対照群に比し，Autograph 像は濃く濾胞内 $\mathrm{I}^{131}$ の沈着が多量に認められ， 他の estrogen 投与 3 群（全量 $0.5 \mathrm{mg} ， 50 \gamma ， 5 \gamma$ ) では殆んど対照群之美異なくAutograph 像も概ね相似た 所見を得た。

2. progesterone 投与成綪

1) 甲状腺 $\mathrm{I}^{131}$ 掑取率 (第 2 表, 第 3 図)

progesterone を投与した 3 群は夫々対照群に比して有意の差を以つて減少を示した。（投与全量 $25 \mathrm{mg}$ ， $2.5 \mathrm{mg}, 0.25 \mathrm{mg}$ では $\mathrm{P}<0.05)$.

第 3 図 去勢後 Progesterone 投与時の甲状腺機能

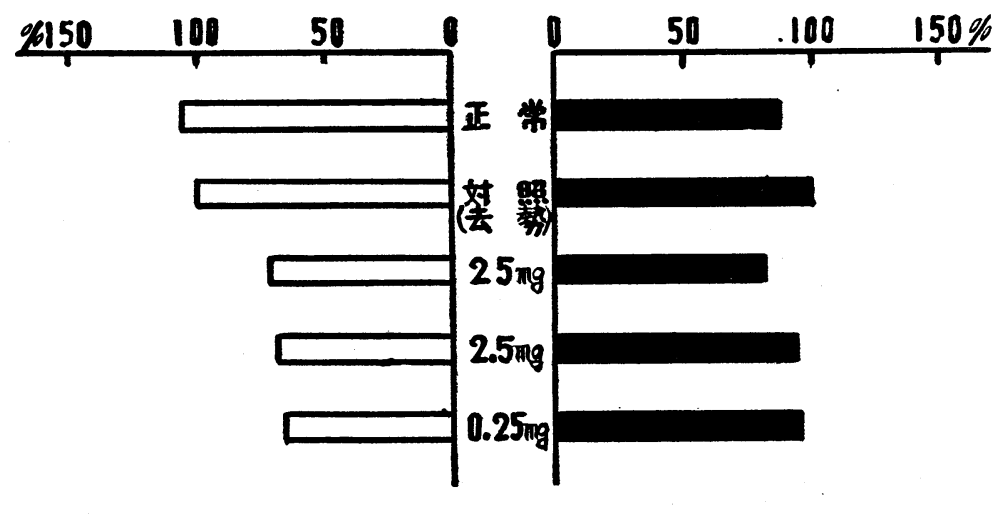

甲状腺 $\mathrm{I}^{131}$ 摂取率

血清 $\mathrm{I}^{131}$ のPBI 転換率

2) 血清 $I^{131} の$ PBI 転換率（第 2 表，第 3 図）

progesterone を投与した 3 群共対照群に比して著明な変化は認められない.

3) 甲状腺重量 (第 2 表)

progesterone を投与した 3 群共対照群に比して特定の变化はみられない.

4) 甲状腺の組織学的所見

progesterone を投与した 3 群共組織学的には対照群に比較して明らかな变化は綛め難い.

5) Radioautograph 亿依る成績

progesterone を投与した 3 群共対照群に比し濾胞内の ${ }^{131}$ 沈着が少なく, 明らかに Autograph 像は淡 い.

\section{3. androgen 投与成綪}

1) 甲状腺 $\mathrm{I}^{131}$ 摂取率（第 2 表，第 4 図）

androgen を投与した 3 群共対照群に比して有意の変化は認められない.

2) 血清 $I^{131}$ の PBI 転換率 (第 2 表, 第 4 図)

androgen を投与した 3 群共対照群に比し明らかな変化はない.

3) 甲状脉重量 (第 2 表)

androgen を投与した 3 群共対照群に比し特定の変化は認められない.

4) 甲状腺の組織学的所見

androgen を投与した 3 群共刘照群に比して組織学的に著明な变化は办られない.

5) Radioautograph 依る成績 
第 4 図 去勢後 Androgen 投与時の甲状腺機能

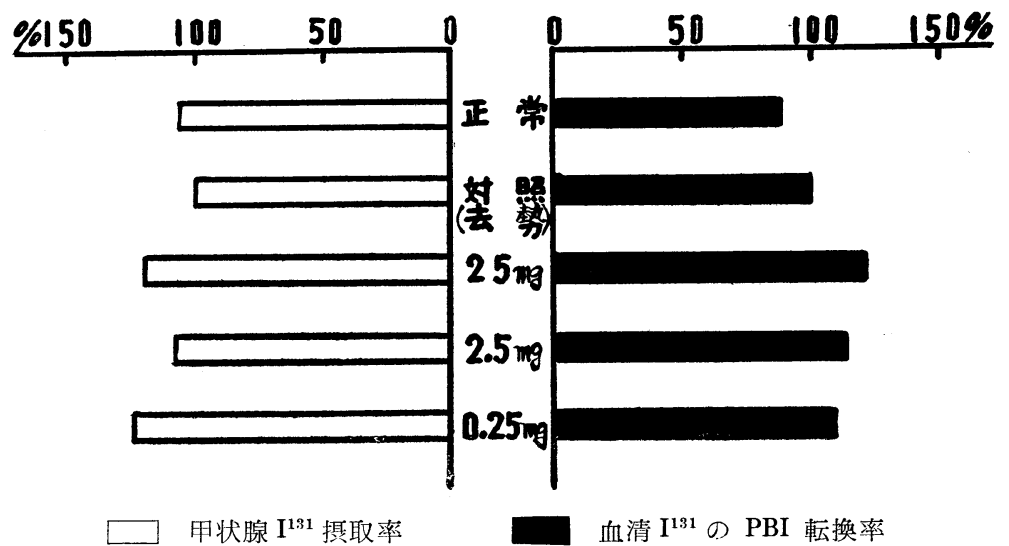

androgen を投与した 3 群共対照群に比して濾胞内の $I^{131}$ 沈着は略々同程度で，Autograph 像も概ね相 似た所見を得た。

\section{第 4 節 総括並びに考按}

\section{1. estrogen 投与に就いて}

estrogen の甲状腺に及ぼす影響に就いては組織学的並びに機能的に諸家により種々の研究が行われてい る. Engstrom $(1952,1954)^{192}{ }^{2 n)}$ らは臨床的に estrogen を投与して甲状腺機能の九進を認めているが，男女 の間に差異のあることを報じ，Lederer $(1953)^{21)}$ は閉経期及び卵巣剔除婦人に長期に亘り大量の estrogen 療法を続けると hyperthyroidism の症状が出現すると述べている.

次に雄性動物に estrogen を投与した時の甲状腺変化に就いて研究した従来の業績をみると, Mercier-Parat $(1952)^{8)}$ は雄ラットに estrogen として 1-methyl-bis-dehydrodoisynol 酸（毎日 $2 ， 8$ 及び100 $\mu \mathrm{g} ， 12$ 日間） を投与し，甲状腺重量並びに組織学的所見から estrogen の作用はその投与量によつて異なるとし，毎日 2 ，

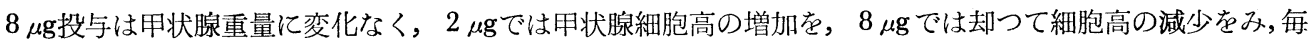
日 $100 \mu \mathrm{g} て ゙ は$ 細胞高の減少著しく, 甲状腺重量屯 $7 \%$ 減少率を認めたと報告している. Money $(1950,1951)$ ${ }^{22}{ }^{23}$ ) らは雄ラットに estrone 毎日50r及び estradiol benzoate 毎日 $1 \mathrm{mg}$ を10日間投与した処，甲状腺重量は 不変であつたと述へ，高折 $(1954)^{24)}$ は倠雄ラットに estradiol を投与し，甲状腺重量は投与量に比例して 増大するととを認め，尚動物の性による差異は殆んどなかつたと述べている．私は去勢後 2 週を経た雄ラッ トに estrogen を投与した処，その投与量の大小に拘らず甲状腺重量は対照に比し明らかな变化を認め得な かつた. 即ち私の用いた量及び期間に関する限り，estrogen は去勢雄ラットの甲状腺重量に対して著明な影 響を及ばさないと云いうる。

甲状腺の組織学的所見に就いては高折 $(1954)^{24)}$ は雌雄ラットを用い, estradiol 1 日15r，11日間投与では 刘照之著変なく，1日 50〜 100r，20〜30 日間投与では顕著な実質性甲状腚腫像を呈したと報告している. Vlyssides (1951) ${ }^{25)}$ らは estradiol propionate（毎日50～10000I.U. 3 日間）投与は正常及び去勢雄モルモッ トの甲状腺に組織学的変化を惹起しないと述べ，Morrell (1941) 26) らは正常並びに去勢雄ラットの甲状腺は stilbestrol 及び天然の estrogen 投与により濾胞上皮細胞の破壊像を認めたと云い，尚，乙の変化は投与量， 投与期間には無影響であつたと報告している。斯くの如く estrogen の甲状腺組織えの影響は未だ研究者に より一定していないが，私の成績では estrogen 投与量の大小に拘らず（投与期間は全て 5 日間）投与 4 群 共, 甲状腺の組織像は対照群に比して著变を認め難いが，一般に軽度の機能九進像を呈すると思われる所見 を得た. 即ち対照群との間に顕著な差異を認め得たかつたのは， estrogen の投与期間が短かい為と考えら れる。 
次に estrogen 投与時の甲状腺機能を放射性沃度 $I^{131}$ を用いて検討した成績では，Zingg (1953) ${ }^{27}$ らは 3 人の精神病男子に estradiol を投与し甲状腺 $I^{131}$ 掑取量の減少を認もたが，血漿 PB I I $^{131}$ 含有量は不定の

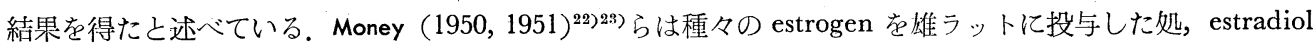
benzoate $50 \gamma$ 投与では甲状腺 $\mathrm{I}^{131}$ 摂取率の減少を，每日 $1 \mathrm{mg} ， 10$ 日間投与では著変なく， estrone の500

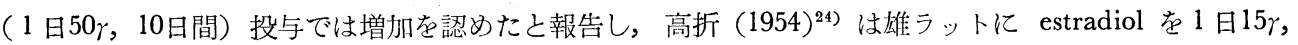
11日間投与では甲状腺 $\mathrm{I}^{131}$ 摂取率，血嶈 $\mathrm{PBI}^{131}$ 含有量に变化なく，estradiol 1 日30〜 50 r，30〜35日間投 与では減少を認めた。 即ち estradiol はその投与量に逆比例して甲状腺 $\mathrm{I}^{131}$ 摂取率及び血漿 $\mathrm{PBI}^{131}$ 含有量 の減少傾向を示す事実から，estradiol を一種の抗甲状腺物質と仮定した. Feldman (1956) 28)292 は正常雌雄, 去勢雄，下垂体摘出雌ラットを用い，短期間の estrogen 投与は妇状腺の $\mathrm{I}^{131}$ 摂取率を増加せしぬ，長期間 （15日或はそれ以上）の投与は甲状腺摂取率を増加せしめないか，又は抑制すると述べ，尚， estrogen 投与 によりラット血清中の $\mathrm{PBI}^{131}$ 含有量は対照よりも明らかに増加すると述べている.

私は去勢後 2 週を経た雄ラットに estradiol benzoate を 1 日 $1 \mathrm{mg}, 0.1 \mathrm{mg}, 10 \gamma ， 1 \gamma$ の各量を 5 日間皮 下投与した処，全量 $5 \mathrm{mg}$ 投与群に於ては対照群に比し甲状腺 $\mathrm{I}^{131}$ 摂取率は明らかな増加を認めたが，他の 3 群では著変を認めなかつた，処が estradiol benzoate 投与の全 4 群に於て血清 $\mathrm{I}^{131}$ の PBI 転換率が明 らかに増加を来たした事実は興味深い. 即ち私の用いた量及び期間に於てはその投与量の大小に拘らず去勢 雄ラットに対して estradiol benzoate は，甲状腺から血中への甲状腺ホルモン放出に関し促進的に作用す るものと解せられる。乙の事実は Feldman (1956) ${ }^{29}$ ) が estrogen 投与によりラット血清中の $\mathrm{PBI}^{131}$ 含有量 の増加を来たした成績とよく符合すると云えよう。

教室の山口 $(1957)^{1)}$ は去勢後 2 週を経て甲状腺 $\mathrm{I}^{131}$ 攝取率，及び血清 $\mathrm{I}^{131}$ の PBI 転換率が共に対照よ り明らかに低下している去勢雌ラットに estradiol benzoate を投与した処，甲状腺の $I^{131}$ 摂取率は何れも 増加し正常值迄回復することを実証し，一方血清 $\mathrm{I}^{131}$ の PBI 転換率は estrogen 单独投与では増加を認め 得なかつたと報告している。乙の事実と私の成績を比較考察してみると，第 1 章に於て記述した如く，去勢

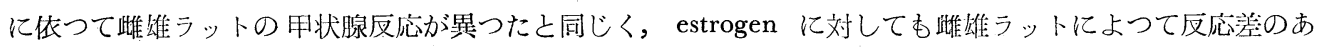
ることが推察される．即ち estrogen は去勢犨ラットに対しては主として甲状腺の沃度捕促を，去勢雄ラッ トに対しては血中への甲状腺ホルモン放出に関して促進的に作用するものと解するのが妥当であ万う。

\section{2. progesterone 投与に就いて}

progesterone の甲状腺に及ばす影響に就いても，従来研究者により色々と報告されて来たが，未だ去勢し た雄ラットに progesterone を投与した際の甲状腺機能を検討した研究業績は見当らない. progesterone 投 与時の甲状腺機能を研究した動物実験の業績を通覧すると，先づ組織学的所見から Knaus $(1923)^{30)}$ は雙亏 ットに progesterone を投与して甲状腺機能低下像を認め，Alexiu (1939) ${ }^{311}$ は progesterone 投与により正 常及び去勢雌ラットの甲状腺は小型濾胞の増加，コロイドの減少，上皮細胞の肥大増殖を来たすと述べてい

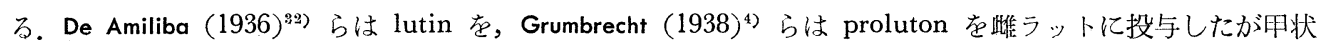
腺は変化を受けなかつたと報告し，高折 $(1954)^{24)}$ は雌雄ラットに progesterone を毎日 $1 \mathrm{mg}$ 短期間 (10 日間) 投与した時には膠様甲状腺腫に似た組織像を認め，長期間（30３3日間）投与すると増殖傾向を，每 日 $5 \mathrm{mg} 27$ 日間投与では一㬝著明な 増殖傾向並びに一部に上皮細胞の变性像を認めたと述べている。

私は去勢後14日を経た成熟雄ラットに progesteron（1日 $5 \mathrm{mg} ， 0.5 \mathrm{mg} ， 50 \gamma$ 夫々 5 日間）を投与した が，甲状腙重量並びにその組織学的所見は何れも対照に比して著明な変化を認め得なかつた. 本所見は雌う ットに黄体ホルモンを投与した De Amilbia (1936) ${ }^{32)}$ ，Grumbrecht (1938) ${ }^{4}$ らの成績及び去勢後14日の雌亏 ットに progesterone を投与した山口 (1957) ${ }^{1)}$ の成績とよく一致し，去勢雄ラットの甲状腺組織に対して も progesterone は著明な影響を及ぼさないと解せられる。

次に放射性沃度 $I^{121}$ を以つて甲状腺機能を検討した実験では，Zingg (1953) 27) らは 3 人の男子に progesterone を毎日 $25 \mathrm{mg} 6$ 日間与え，甲状腺 $\mathrm{I}^{131}$ の蓄積並びに $\mathrm{I}^{131}$ 放出は共に低下する傾向にあると述へ， Money $(1950,1951)^{22223)}$ らは雄ラットに progesterone 1 日，5 mg及び pregnenolone 1 日，30mgを10日 
間投与すると甲状腺 $\mathrm{I}^{132}$ 摂取率は増加し，pregnenolone 1 日 $15 \mathrm{mg}, 10$ 日間投与では $\mathrm{I}^{131}$ 摂取率は䁇ろ低 下する傾向を認めたと報じ，高折 $(1954)^{24)}$ は雄ラットに progesterone を 1 日 $1 \mathrm{mg}$ ，33日間投与し甲状 腺 $\mathrm{I}^{131}$ 摂取率，血漿 $\mathrm{PBI}^{131}$ 転換率は何れも対照より増加を示し，1日 $5 \mathrm{mg} ， 27$ 日間投与では反対に $\mathrm{I}^{131}$ 摂取率 (40\%の減少), 血漿 $\mathrm{PBI}^{131}$ 転換率は減少を示したと報告している.

私は去勢後14日経た成熟雄ラットに progesterone を投与した処，甲状腺 $\mathrm{I}^{131}$ 摂取率はその投与量の大小 を間わず，著明な低下を来たした，一方血清 $\mathrm{I}^{131}$ の PBI 転換率は明らかな変化を認め得なかつた. 即ち私 の用いた量及び期間に関する限り，甲状腺 $\mathrm{I}^{131}$ 摂取率からみて， progesterone は去勢雄ラットの甲状腺に 対し抑制的に作用するあのと考えられる。教室の山口（1957) ${ }^{1)}$ は去勢後14日を経て甲状腺機能の低下した 成熟雌ラットに progesterone を投与し，甲状腺 $\mathrm{I}^{131}$ 攝取率，血清 $\mathrm{I}^{131}$ の PBI 転換率は共に対照群に比 し著変を認めなかつたと報告しているが，私の実験成績と併せ考察してみると，progesterone は去勢雌雄 ットの甲状腺に対して夫々異つた反応を示すあのと考えられる. 即ち progesterone は雌ラットよりむ垫 雄ラットの甲状腺に対し鋭敏に反応することを知り得た．然し乍ら何故に progesterone が去勢雄ラットの 甲状腺に対して敏感に反応を示すかの本態は明らかでないが, Pincus (1943) ${ }^{332}$ らに依れば progesterone の 人体内に於ける代謝殊に pregnandiol への転換には子宮が重大な役割を果しており，男女によつて pregnandiol への転換率が異なり男は著しく低いと報告している。他方 progesterone は生体内に於て corticoid の前階物質であると見做されており， corticoid が甲状腺機能を抑制することは Albert (1952) ${ }^{34)}$ ，Grant $(1955)^{955}$ ら多くの研究者の認めている処である. 以上の事からみて去勢雄ラットに於ては投与された progesterone が主として corticoid に変換して甲状腺機能を抑制したものと解せられる.

\section{3. androgen 投与に就いて}

Zingg $(1953)^{27)}$ らは 4 人の精神病患者に testosterone を毎日 $25 \mathrm{mg} ， 6$ 日間投与したが，甲状腺 $\mathrm{I}^{131}$ 摄 取及び $\mathrm{I}^{131}$ 放出は影響を受けないと述べている. androgen 投与時の甲状腺機能を検索した動物実験の業績 をみると, 先づ甲状腺重量並びに組織所見から Leathem $(1951)^{36)}$ は成熟正常並びに去勢ラットに testosterone propionate (以下 testosterone prop. と略す) を投与したが，甲状腺重量は不変であると述へ，Burris $\left.(1953)^{37}\right)$ らは雌雄の犢に testosterone prop. を投与し甲状腺重量の増加と分泌克進像を認めたと報告し, Castellani (1952) ${ }^{33)}$ は成熟雄モルモットに testosterone prop. を毎日0.1，1.0，及び2.5mg，15日間投与し， $0.1 \mathrm{mg}$ 群では中等度の甲状腺機能九進像を，1.0 及び $2.5 \mathrm{mg}$ 投与群では逆に機能低下像を認めたと述へ， 高折 $(1954)^{24)}$ は雌雄ラットに testosterone prop. を1 日2.5mg，15日間投与した時には甲状腺重量に変化 なく，30日間投与群では殆んど全例に重量の増加を認め，又組織学的にも実質性甲状腺腫と云うべき増殖像 を得たと述べている．私は去勢後14日の雄ラットに testosterone prop. (1 日，5 mg，0.5mg，50r夫々 5 日間）を投与した処，甲状腺重量並びに組織斦見は何れも対照との間に明らかな差異を認め得なかつた。

次に $I^{131}$ を用いた実験では Money $(1950,1951)^{22) 23)}$ らは雄ラットに testosterone prop. 及び testosterone を每日各々 $5 \mathrm{mg} 10$ 日間投与し，甲状腺 $\mathrm{I}^{131}$ 掑取率の増加を，又，高折 (1954) ${ }^{24)}$ は雄ラットに testosterone prop. を毎日 $2.5 \mathrm{mg} 32$ 日間投与し，甲状腺 $\mathrm{I}^{131}$ 摂取及び血漿 $\mathrm{I}^{131}$ の PBI 転換率は共に増加する傾向を認 めたと報告している. 逆に Gassner (1947) ${ }^{399}$ らは雄ラットに testosterone prop. を長期間投与し甲状腺 $\mathrm{I}^{131}$ 掑取率は低下を来たしたと述べている。一方，Kochakian (1956) 18) らは雄ラットに testosterone prop. を 長期間（1 日 $1 \mathrm{mg} ， 38$ 日間）投与しても甲状腺 $\mathrm{I}^{131}$ 摂取率並びに $I^{131}$ 放出も影響を受けなかつたと報告 している. 私は去勢雄ラットに testosterone prop. を第 2 表に示した如く投与したが，Kochakian (1956) ${ }^{18)}$ らの得た成績と同様に甲状腺 $\mathrm{I}^{131}$ 摂取率及び血清 $\mathrm{I}^{131}$ の PBI 転換率は何れも対照に比し著明な差異を認 め得なかつた。

さて私は去勢後14日を経た雄ラットに上述の如く testosterone prop. を投与した際の甲状腺機能を検討し た処，組織学的所見からも，又， $I^{131}$ の所見からも投与 3 群共対照群に比し著变を認め得たかつた事実は， 
1 章で述べた去勢に依る甲状腺えの影響と同様に，去勢雄ラットの甲状腺は testosterone prop. 投与により 明らかな影響を受けないと云いうる。殊に雄ラット体内内分泌機構に大なる役割を演じていると推定される androgen が雄ラットの甲状腺に対して一定の変化を惹起しないことは興味深い.

\section{第 5 節 結 語}

去勢後14日を経た雄ラットに各種性ホルモンを投与した場合の甲状腺機能を組織学的所見並びに I ${ }^{191}$ を 用いて検索し，次の如き結果を得た。

1) estrogen 投与成績

甲状腺 $\mathrm{I}^{131}$ 摂取率は全量 $5 \mathrm{mg}$ 投与群に於てのみ対照群に比し明らかな增加を示し，全量 $0.5 \mathrm{~cm} ， 50 \gamma$, $5 \gamma$ 投与の 3 群では変化を認めない，血清 $\mathrm{I}^{131}$ の $\mathrm{PBI}$ 転換率は全量 $5 \mathrm{mg}, 0.5 \mathrm{mg}, 50 \gamma, 5 \gamma$ 投与の 4 群共 に增加を示した。甲状腺重量は 4 群共著明な变化はなく, 甲状腺の組織学的所見は 4 群共対照群に比べ著明 な変化は認められないが,一般に軽度の機能㐫進像を示した。

2) progesterone 投与成績

甲状腺 $\mathrm{I}^{131}$ 㠌取率は全量 $25 \mathrm{mg} ， 2.5 \mathrm{mg} ， 0.25 \mathrm{mg}$ 投与の 3 群共対照群に比し有意の減少を示した。血清 $\mathrm{I}^{131}$ のPBI転換率は 3 群共変化を認めない, 甲状腺重量及び甲状腙の組織所見は共に明らかな変化を認わない.

3) androgen 投与成績

甲状腺 $\mathrm{I}^{131}$ 摂取率及び血清 $\mathrm{I}^{131}$ の PBI 転換率は全量 $25 \mathrm{mg}, 2.5 \mathrm{mg}, 0.25 \mathrm{mg}$ 投与の 3 群共対照群に比 し変化はない.甲状腺重量並びそ甲状腺の組織学的所見は 3 群共明らかな変化を認めない.

4) 甲状腺の Radioautograph の成績は概ね各用状腺の $I^{1: 11}$ 摂取率の成績と一致した。

5）以上の実験成績より去勢後14日を経た雄ラットの甲状腺に対する各種性ホルモンの作用効果を総括し てみると，estrogen は甲状腺機能中，捕促沃度を有機化して甲状腺ホルモンとして血中へ放出する過程に対 して促進的に作用し，progesterone は甲状腺での沃度摄取を抑制し，androgenは状腺に対して特異な作 用效果を有しないものと解せられる.

\section{第 3 章＼cjkstart長期去勢の雌雄ラット甲状腺に対する性ホルモン投与の影響}

\section{第 1 節 まえがき}

第 $1 ， 2$ 章では雄ラット甲状腺に対する去勢の影響並びに性ホルモン投与の影響に就いて検討し，雌ラッ 卜の場合之比較して可成の特異性ある所見, 即ち去勢に依る甲状腺えの影響は雄に比し雌の方が迅速且著明 であり，又性ホルモンを投与した時であ雙雄ラットに依つて反応美のあることを知り得たが，私は更に本章 に於ては，去勢後 2 力月の長期を経，甲状腺機能が共に低下した時期の雌雄ラットを用い，乙れに性木ルモ ンを投与した時の甲状腺機能を $\mathrm{I}^{131}$ を以つて榆討し，去勢 2 力月の甲状腺に対して性ホルモンが雌雄ラッ 卜に依つて如何なる反応差を示すすのかを検討した。

\section{第 2 節 実験材料及び実験方法}

実験材料及び実験方法は第 1 章に於て述べたすのと同一である．成熟雙ラットの去勢手術は背部より行い 卵巣を周囲の脂肪組織と共に剔出した。

\section{第 3 節 実験成續}

\section{1. 去勢に依る成綪}

1) 甲状腺 $\mathrm{I}^{131}$ 覜取率 (第 3 ，第 4 表)

雌ラットでは正常無処置群に比し明らかな減少を認めたが（ $\mathrm{P}<0.05)$, 雄ラットでは稍々減少の傾向を 示すが正常無処置群之の間に有意の変化はない.

2) 血清 $I^{131}$ のPBI 転換率（第 3 ，第 4 表）

雌雄ラット共正常無処置群に比して明らかな変化はない.

3) 甲状腺重量及び甲状腺の組織学的所見

甲状腺重量は雌雄ラット共に正常無処置群との間に著变を認めない，甲状腺の組織学的所見は雌雄ラット 
共, 大型濾胞の增加，小型滤胞の減少，濾胞上皮の扁平化，コロイドの滤胞内充満ら，正常無処置群に比し て明らかな機能低下像を認め, 所謂去勢甲状腺像の所見を得た。

第 3 表 去勢後（2 ケ月）各種性ホルモン投与時の計測平均值

\begin{tabular}{|c|c|c|c|c|c|c|c|c|c|}
\hline \multirow[b]{2}{*}{ 우 } & \multirow{2}{*}{$\begin{array}{l}\text { 投日 } \\
\text { 与数 }\end{array}$} & \multirow{2}{*}{$\begin{array}{c}1 \text { 旦 } \\
\text { 投与量 }\end{array}$} & \multirow{2}{*}{ 投与全量 } & \multirow{2}{*}{$\begin{array}{l}\text { 動 } \\
\text { 物 } \\
\text { 数 }\end{array}$} & \multirow{2}{*}{$\begin{array}{l}\text { 終体重 } \\
(\mathrm{g})\end{array}$} & \multicolumn{2}{|r|}{ 甲 } & & \multirow{2}{*}{\begin{tabular}{|c|c|c|c|} 
血 清 \\
P B I 転換率 \\
$(\%)$
\end{tabular}} \\
\hline & & & & & & $\begin{array}{l}\text { 重量 } \\
(\mathrm{mg})\end{array}$ & $\begin{array}{l}\text { 体重 } 100 \mathrm{~g} \text { 当 } \\
\text { の重量( } \mathrm{mg} \text { ) }\end{array}$ & $\begin{array}{c}\mathrm{I}^{131} \text { 撖取率 } \\
(\%)\end{array}$ & \\
\hline 正常無処置 & 5 & $0.5 \mathrm{cc} \triangle$ & $2.5 \mathrm{cc} \Delta$ & 5 & 171.7 & 12.8 & $7.45 \pm 1.28$ & $13.60 \pm 0.85^{*}$ & $62.84 \pm 1.79$ \\
\hline 対照(去勢) & 5 & $0.5 \mathrm{cc} \triangle$ & $2.5 \mathrm{cc} \triangle$ & 5 & 217.4 & 11.4 & $5.24 \pm 0.83$ & $10.55 \pm 0.38$ & $53.18 \pm 3.60$ \\
\hline \multirow{3}{*}{$\begin{array}{l}\text { estradiol } \\
\text { benzoate }\end{array}$} & 5 & $1 \mathrm{mg}$ & $5 \mathrm{mg}$ & 5 & 179.4 & 13.8 & $7.69_{ \pm 0.92}$ & $24.06 \pm 1.56^{* *}$ & $59.87 \pm 3.98$ \\
\hline & 5 & $10 \gamma$ & $50 \gamma$ & 5 & 194.6 & 15.0 & $7.71 \pm 0.61$ & $21.79 \pm 0.75^{* *}$ & $59.80 \pm 3.28$ \\
\hline & 5 & $1 \gamma$ & $5 \gamma$ & 4 & 171.2 & 14.0 & $8.18 \pm 1.08$ & $21.17 \pm 2.41 * *$ & $62.15 \pm 2.86$ \\
\hline \multirow{2}{*}{ progesterone } & 5 & $5 \mathrm{mg}$ & $25 \mathrm{mg}$ & 4 & 170.5 & 12.8 & $7.51 \pm 1.20$ & $14.77 \pm 1.57^{*}$ & $54.16 \pm 2.90$ \\
\hline & 5 & $50 \gamma$ & $250 \gamma$ & 4 & 196.5 & 12.0 & $6.11 \pm 0.71$ & $14.28 \pm 2.50$ & $53.43 \pm 3.01$ \\
\hline testosterone & 5 & $5 \mathrm{mg}$ & $25 \mathrm{mg}$ & 4 & 196.0 & 12.3 & $6.28 \pm 1.45$ & $8.00 \pm 0.69 * *$ & $41.67 \pm 4.17$ \\
\hline propionate & 5 & $50 \gamma$ & $250 \gamma$ & 4 & 206.7 & 14.0 & $6.77 \pm 0.87$ & $11.30 \pm 0.89$ & $56.87 \pm 4.88$ \\
\hline
\end{tabular}

有意差は各計測平均值を対照のそれと比較したものである

* $\mathrm{P}<0.05 \quad * * \mathrm{P}<0.01 \quad$ 土开均誤差を示す $\triangle$ 精製胡麻油のみ

第 4 表 去勢後（２ケ月）各種性ホルモン投与時の計測平均值

\begin{tabular}{|c|c|c|c|c|c|c|c|c|c|}
\hline \multirow[b]{2}{*}{$\hat{\jmath}$} & \multirow{2}{*}{$\begin{array}{l}\text { 投日 } \\
\text { 与数 }\end{array}$} & \multirow{2}{*}{$\begin{array}{c}1 \text { 日 } \\
\text { 投与量 }\end{array}$} & \multirow{2}{*}{ 投与全量 } & \multirow{2}{*}{$\begin{array}{l}\text { 動 } \\
\text { 物 } \\
\text { 数 }\end{array}$} & \multirow{2}{*}{$\begin{array}{l}\text { 終体重 } \\
(\mathrm{g})\end{array}$} & \multicolumn{2}{|r|}{ 甲 } & 腺 & \multirow{2}{*}{$\begin{array}{c}\text { 血 }{ }^{\text {清 }} \\
\text { P B I 転換率 } \\
(\%) \\
\end{array}$} \\
\hline & & & & & & $\begin{array}{l}\text { 重量 } \\
\text { (mg) }\end{array}$ & $\begin{array}{l}\text { 体重 } 100 \mathrm{~g} \text { 当り } \\
\text { の重量 (mg) }\end{array}$ & $\mathrm{I}^{131}$ 摂取率 $(\%)$ & \\
\hline 正常無処置 & 5 & $0.5 \mathrm{cc} \triangle$ & $2.5 \mathrm{cc} \triangle$ & 5 & 203.6 & 16.2 & $7.96 \pm 1.16$ & $0.87 \pm 0.08$ & $59.3 \pm 1.64$ \\
\hline 対照(去勢) & 5 & $0.5 \mathrm{cc} \triangle$ & $2.5 \mathrm{cc} \triangle$ & 5 & 197.5 & 13.4 & $6.78 \pm 1.60$ & $0.83 \pm 0.03$ & $57.8 \pm 2.39$ \\
\hline estradiol & 5 & $1 \mathrm{mg}$ & $5 \mathrm{mg}$ & 4 & 164.5 & 12.6 & $7.66 \pm 1.66$ & $0.82 \pm 0.14$ & $64.9 \pm 4.42$ \\
\hline benzoate & 5 & $1 \gamma$ & $5 \gamma$ & 4 & 185.7 & 15.9 & $8.56 \pm 0.92$ & $1.78 \pm 0.17 * *$ & $81.1 \pm 3.00^{*}$ \\
\hline \multirow[b]{2}{*}{ progesterone } & 5 & $5 \mathrm{mg}$ & $25 \mathrm{mg}$ & 4 & 171.2 & 14.6 & $8.53 \pm 0.74$ & $1.08 \pm 0.20$ & $78.6 \pm 5.10$ \\
\hline & 5 & 50 & $250 \gamma$ & 4 & 175.7 & 13.9 & $7.91 \pm 1.80$ & $1.00 \pm 0.13$ & $76.0 \pm 4.16$ \\
\hline testosterone & 5 & $5 \mathrm{mg}$ & $25 \mathrm{mg}$ & 4 & 189.5 & 14.2 & $7.49 \pm 0.50$ & $1.45 \pm 0.34$ & $74.3 \pm 4.83$ \\
\hline propionate & 5 & $50 \gamma$ & $250 \gamma$ & 4 & 174.5 & 14.3 & $8.19 \pm 0.08$ & $0.76 \pm 0.14$ & $64.0 \pm 3.78$ \\
\hline
\end{tabular}

有意差は各計測平均值を対照のそれと比較したものである

* $\mathrm{P}<0.05 \quad * * \mathrm{P}<0.01 \quad$ 平均誤差を示す $\triangle$ 精製胡麻油のみ

\section{2. estrogen 投与成綪}

1) 甲状腺 $\mathrm{I}^{131}$ 摂取率 (第 3 ，第 4 表，第 5 図）

溶媒のみ投与した対照 (去勢) 群に比して，雌ラットでは estrogen を投与した 3 群共に，有意の差を以 つて増加し（投与全量 $5 \mathrm{mg} ， 50 \gamma ， 5 \gamma \mathrm{P}<0.01$ ） 正常無処置のあのの值よりあ高い増加を示した. 雄ラット では estrogen 全量 $5 \gamma$ 投与群に於て明らかな増加を認め $(\mathrm{P}<0.01)$, 全量 $5 \mathrm{mg}$ 投与群では変化を認めな い.

2) 血清 $I^{131}$ のPBI 転換率（第 3 ，第 4 表，第 5 図） 
第 5 図 去勢後（2 力月） Estrogen 投与時の甲状腺機能

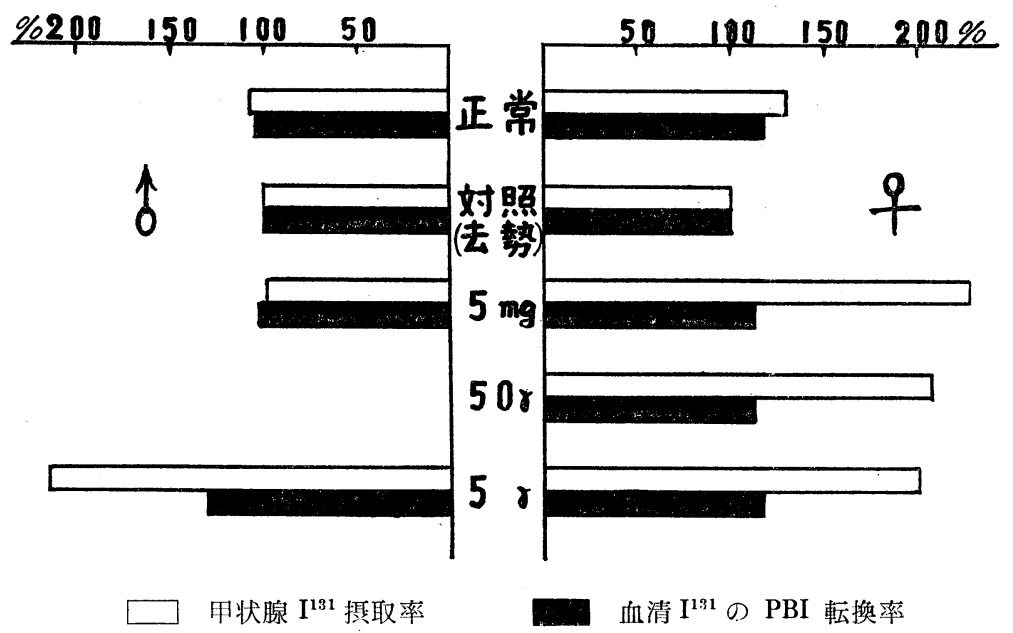

踓ラットは estrogen を投与した 3 群共に，対照（去勢）群に比して明らかな変化は認められない. 雄ラ ットでは estrogen 全量 $5 r$ 投与群に於て明らかなを示し $(P<0.05)$, 金量 $5 \mathrm{mg}$ 投与群では明らかな变化 はない.

3) 甲状腺重量及び甲状腺の組織学的所見

estrogen を投与した雙雄ラット共全群に於て，甲状腺重量及ご甲状腺の組織学的所見は何れ屯対照群に比 して明らかな变化は認められない。

\section{3. progesterone 投与成綪}

1）甲状腺 $\mathrm{I}^{131}$ 摂取率（第 3 ，第 4 表，第 6 図）

雌ラットは progesterone 全量 $25 \mathrm{mg}$ 投与群に於ては対照群に比し有意の増加を示し $(\mathrm{P}<0.05)$, 全量 250 投与群では増加の傾向にあるが有意の差は認められない，雄ラットは progesterone を投与した 2 群共 対照群に比し稍々増加の傾向を示すが明らかな变化はない。

2）血清 $I^{131}$ の PBI 転換率（第 3 ，第 4 表，第 6 図）

雌雄ラットに progesterone を投与した全 2 群共対照群に比して著明な变化は認められない.

第6図去勢後（2 力月）Progesterone 投与時の甲状腺機能

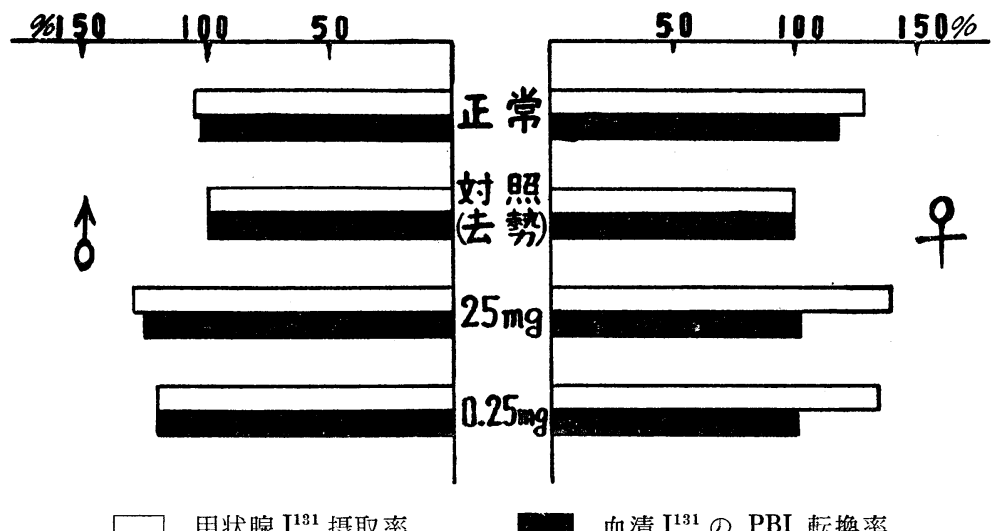

第35巻 第 7 号 
3) 甲状腺重量及び甲状腺の組織学的所見

progesterone を投与した雙雄ラット共全 2 群に於て, 甲状腺重量及び甲状腺の組織学的所見は対照群に比 して著変は認められない.

4. androgen 投与成績

1) 甲状腺 $\mathbf{I}^{131}$ 掑取率 (第 3 ，第 4 表，第 7 図)

雌ラットでは androgen を全量 $25 \mathrm{mg}$ 投与した群に於ては対照群に比して有意の減少を示し $(\mathrm{P}<0.01)$ 全量 $250 \gamma$ 投与群では著明な変化はない，雄ラットでは androgen 全量 $25 \mathrm{mg}$ 投与群に於て稍々增加の傾向を 示すが，250 投与群と共に対照群に比して有意の変化は認められない。

第 7 図 去勢後 ( 2 力月) Androgen 投与時の甲状腺機能

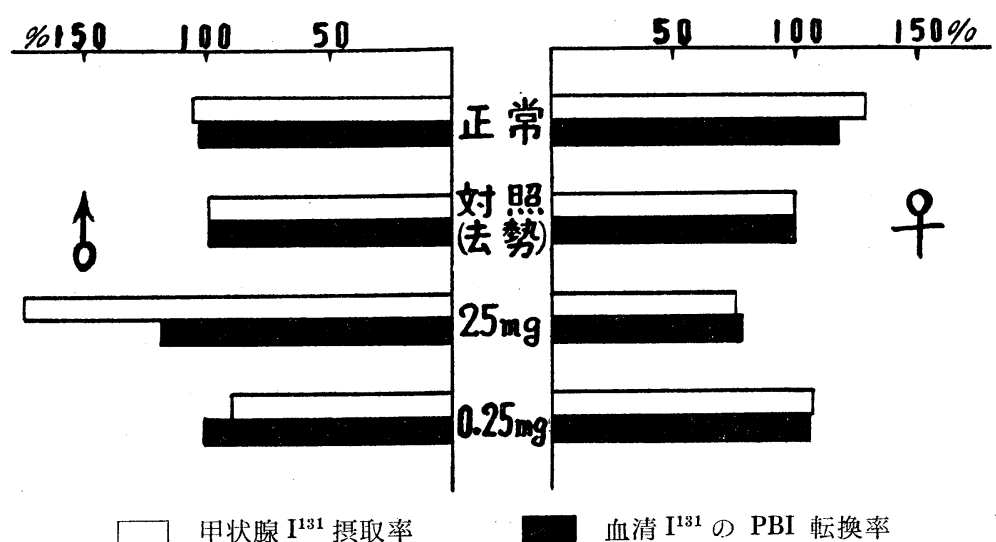

2) 血清 $I^{131}$ のPBI 転換率（第 3 表，第 4 表，第 7 図）

雌雄ラット共 androgen を投与した全 2 群に於ては対照群と比較して明らかな変化はない.

3) 甲状腺重量及び甲状腺の組織学的所見

雌雄ラット共 androgen を投与した全 2 群に於て甲状腺重量並びに組織学的には対照群に比して著明な差 異はみられない。

\section{第 4 節 総括並びに考按}

\section{1. 去勢に就いて}

雄性動物を去勢した時に起る甲状腺変化に就いて研究した業績は既に第 1 章に於て述べたので省略し，茲 では雙性動物を去勢した場合の甲状腺機能に就いて研究した成績を通覽してみると，先づ甲状腺重量に就い て州藤 $(1930)^{11)}$ は家象で (去勢後 1 週及び 4 週), Andersen \& Kennedy (1933) 及び 8 週)，小川 (1954) $)^{40)}$ らはラットで（去勢後 2 週）夫々甲状腺重量は減少すると云い，Paschkis (1948) 41)らはラットで (去勢後60日), Schilling \& Laqueur (1941) ${ }^{43)}$ はラットで (去勢後140日), Brauner (1950) ${ }^{43}$ らもラットで（去勢後 5 週以内）去勢に依つて甲状腺重量は変化しないとし，松村 $(1944)^{44)}$ は家鬼で（去 勢後 3 カ月及び 6 カ月)，佐藤（1957) ${ }^{45)}$ はラットで (去勢後30日)，林 (1955) ${ }^{46)}$ らはラットで夫々去勢後 甲状腺重量が增加すると報告し，Hatai (1915) $)^{\eta}$ はラットで去勢時期に依つて甲状腺重量が異つた反応を示 すと述へている．次に甲状腺の組織学的所見から Kippen \& Loeb (1936) ${ }^{12}$ はモルモットで (去勢後 1 週), Dogliotti (1934) $)^{47)}$ は家鬼で (去勢後40日), Proto (1934) ${ }^{48}$ は大で (去勢後12 20日), 松村 $(1944)^{44)}$ は家 鬼で (去勢後 3 及び 6 力月）去勢に依り甲状腺機能は元進を来たすとし，Andersen \& Kennedy (1933) ${ }^{6}$ は

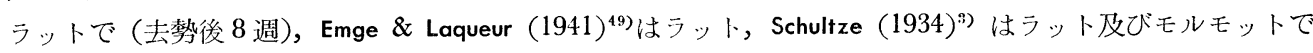
夫々組織学的所見から機能低下を来たすと判定し，一方 Chouke $(1930)^{13)}$ ，Starr \& Bruner (1935) ${ }^{509}$ はモル 
モットで去勢が甲状腺に無影響であるとした. Grumbrecht \& Loeser (1938) ${ }^{4) 5)}$ はラットで去勢後当初は機能 低下を，一定期間後（Grumbrecht は14日，Loeser は18日）には却つて機能克進像を呈すると述べている.

次に $I^{131}$ を用いた実験では Paschkis (1948) ${ }^{41)}$ らはラットで去勢に依つて（去勢後50日）甲状腺 $\mathrm{I}^{131}$ 摂 取率は影響を受けないとし，小川 $(1954)^{40)}$ らはラットで去勢後既に 2 週間で，佐藤 $(1957)^{45)}$ は30日で $I^{131}$ 掑取率の低下を報じ，又，林 $(1955)^{46)}$ らはラットで去勢後 5〜10日では $\mathrm{I}^{131}$ 摂取率の低下を，20～30日 後では逆に $\mathrm{I}^{131}$ 摂取率の増加を認めている.

私は去勢後 2 カ月の長期を経て雌雄ラットの甲状腺機能が，性別にみて如何なる反応差を示すあのかを知 るため $I^{131}$ を用いて実験した処，甲状腺 $I^{131}$ 摂取率は雌では有意の減少を，雄では有意ではないが減少す る傾向を認めた. 血清 $\mathrm{I}^{131}$ の PBI 転換率は雏雄ラット共正常無処置群と比較して明らかな変化を認め得な かつた. 一方, 甲状腺重量は雌雄ラット共正常無処置群と比較して著变を認め得ないが，組織学的には両者 共明らかな機能低下像を呈する. 即ち去勢後 2 カ月の長期を経たラットでは共に甲状腺機能が低下すること を知り得たが，その程度は第 1 章に於て去勢後 2 週を経た雌雄ラットに得られた甲状腺所見と同様に, 甲状 腺 $\mathrm{I}^{131}$ 掑取率の低下度からみて雄に比し雌の方が著明であると解せられる。茲にも去勢に依る甲状腺機能 には性差の存在するととが実証された。

\section{2. estrogen 投与に就いて}

estrogen 投与の甲状腺機能に及ばす影響に就いては，甲状腺を刺戟するという報告と，反対に抑制すると いう成績，或は影響がないという報告があり，未だ意見の一致をみていない。乙れら成績の不一致の原因は 主に estrogen の投与量と投与期間に左右されるようである。 (Pincus \& Werthessen (1933) ${ }^{51)}$, Tagliaferro $(1933)^{52)}$, Freudenberger \& Clausen $(1937)^{53354)}$ ，Wolterink $(1950)^{55)}$ ，Lerman $\left.(1950)^{56)}\right)$. 投与量に就いて Lerman $(1950)^{56)}$ は生理的範囲の微量では甲状腺機能を高め，大量では却つて抑制するとし，Wolterink $(1950)^{55}$ らはマウス，ラットで少量は $I^{131}$ 摂取率を高め，大量では減少させると報じ，投与期間に就いて Feldman (1956) ${ }^{28)}$ らはラットで短期間の estrogen 投与は甲状腺 $\mathrm{I}^{131}$ 掑取率を増加せしめ，15日又はそれ 以上の長期間投与は摂取率を増加せしめないが，或は抑制すると報告し，Tagliaferro（1933）占2) はラット及 びモルモットで 5 10日間の estrogen 投与は甲状腺に増殖像を，30日間投与では元の組織像に復すると述

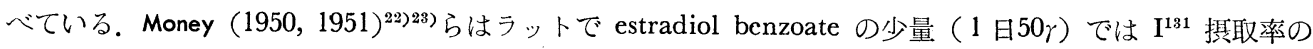
減少を，大量（1日 $1 \mathrm{mg}$ ) では無影響であると報告している。

次に甲状腺重量及び組織学的所見から estrogen 投与-時の甲状腺機能を検討した成績をみると，雄動物に 就いて Mercier-Parot (1952) $\left.{ }^{3}\right)$ はラットで estrogen 投与量に依つて甲状腺重量及び組織像は夫々異つた反 応を来すと述心゙，Vlyssides $(1951)^{25)}$ らはモルモットで甲状腺組織に，Money $(1950,1951)^{2223)}$ らはラット で estrogen 投与により甲状腺重量は無影響であるとし，高折 (1954) 24) は雌雄ラットで甲状腺重量は投与

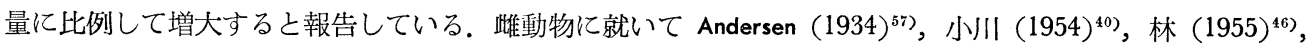
佐藤 $\left.(1957)^{45}\right)$ はラットで estrogen 投与により甲状腺重量の増加を，斉藤 $(1930)^{11)}$ は牛卵巣実質を家鬼 に投与し，Pincus $(1933)^{51)}$ ，Freudenberger $(1937)^{53354}$ らは Theelin をラットに投与し夫々甲状腺重量の減 少を認め，一方 Leonard $(1931)^{58)}$ ，Schilling \& Laqueur (1941) $\left.{ }^{42}\right)$ はラットで estrogen 投与が甲状腺重量に 無影響であると述べている． 組織学的所見から Andersen $(1934)^{57)}$, Tagliaferro (1933) ${ }^{52)}$, De Amilibia $(1936)^{32)}$ らはラットで少量の estrogen は甲状腺に明らかな増殖像を来たしたと報じ,一方 Hyel $(1934)^{59)}$, Karp \& Kostkiewicz $(1934)^{60)}$, Frank $(1937)^{61)}$, Kreitmar \& Sieckman $(1939)^{62)}$, Gardner (1949) ${ }^{63)}$ は estrogen 投与により逆に甲状腺機能低下像を認めたと云い，Heyl $(1934)^{59)}$ ，Grumbrecht $(1938)^{4) 5)}$ らはか〉る甲状 腺機能の低下は下垂体の thyrotropin 減少に基づくことを実験的に証明した。 一方 De Amilibia (1936) ${ }^{32}$ らは estrogen が thyrotropin 分泌の増量を誘発し，従つて短期間投与では甲状腺増殖を来たすが，長期に 及ぶと甲状腺は疲学性萎縮に陷るものと解釈した。而し Alexiu (1939) ${ }^{31)}$ ，Desclin (1951) ${ }^{64)}$ は長期間大量を 投与しても甲状腺に増殖像を認めたと報告している。 また Leonard (1931) ${ }^{58)}$, Schilling \& Laqueur $(1941)^{42)}$, Arnold $(1938)^{65)}$ らのように estrogen は甲状腺重量及び組織像に変化を及ぼさないと云う報告むある。以 
上の如く estrogen の甲状腺えの影響は区々であるが，大部分はその投与量及び投与期間にかつつているも のと考えられる.

次に estrogen 投与時の甲状腺機能を放射性沃度を用いて実験した成績では，雄動物に就いては既に第 2 章で記述済みであるので省略し，倠動物に estrogen を投与した実験では Paschkis (1948) ${ }^{41)}$ らはラットで estrogen 投与が甲状腺 $\mathrm{I}^{131}$ 摂取率に無影響であると云い，Müller \& Aeppli (1949) ${ }^{66)}$ ，佐藤 $(1957)^{45)}$ はラ ットで $I^{131}$ 椇取率の減少を報じている. 小川 $(1954)^{40)}$ らは少量の estrogen 投与はをれを増加せしめると 述べ，林 $(1955)^{45)}$ らはラットで estrogen の短期間投与は甲状腺に促進的に，長期間投与では抑制的に作 用するとしている.

去勢雌雄動物に estrogen を投与し甲状腺機能を検討した研究をみると，雄動物に就いては第 2 章で既に述 バたので茲では省略する。雙動物に就いて Leiby $(1933)^{67)}$ は去勢後 3 週間を経たラットに theelol を投与し て甲状腺の肥大を認め，Andersen (1934) ${ }^{57}$ は amniotin の投与が去勢ラットの萎縮した甲状腺の重量及 び組織像を正常汽恢復せしめると報じ，Grumbrecht \& Loeser (1938) 時には甲状腺の去勢変化に効果なく， estradiol benz. 又は ketohydroxyestrin を子宮腔内に投与すると， 去勢に依つて惹起される甲状腺変化を防止し，去勢後の萎縮が起つている時期に投与すれば明らかに甲状腺 は正常の状態に恢復することを見出した，松村 $(1944)^{44)}$ は去勢後 3 . 力及及び 6 力月を経過した家鬼に卵巣 ホルモン製剤を投与すれば去勢後に起る膠様性甲状腺腫像は消失し，正常家鬼の甲状腺像を呈すると云い， 小川 $(1954)^{40)}$ らは去勢により減少した甲状腺重量が estrogen 投与により元に恢復することを認め, Soliman \& Reineke (1955) ${ }^{68)}$ は $I^{131}$ を用い去勢後の倠ラット甲状腺は estradiol benz. の少量投与により $I^{131}$ 掑取 率が明らかに増加すると報告している。鈴木 $(1957)^{69)}$ は去勢婦人に estradiol benz., estradiol valerianate 投与により何れも甲状腺 $\mathrm{I}^{131}$ 摂取率0増加を認めている.

私は去勢後 2 力月を経て甲状腺機能が共に低下した雌雄ラットに estradiol benzoate 5 日間（雌では 1 日 $1 \mathrm{mg} ， 10 \gamma ， 1 \gamma$ を雄では 1 日 $1 \mathrm{mg} ， 1 \gamma$ を）投与し甲状腺機能を検討した処，雌雄ラット共甲状腺重 量並びに甲状腺の 組織学的所見は対照群に比して著変を認め得なかつた。前章に於てむ記述した如く， estrogen. が去勢期間の長短に拘らず雌雄 ラットの甲状腺組織 に明らかな変化を示さない事実は, estrogen の投与期間が短いためと考えられる。次に甲状腺 $\mathrm{I}^{131}$ 掑取率は去勢雌ラットでは estrogen 投与量の大小を 問わず，低下した $I^{131}$ 摂取率を正常無処置群の值以上に増加せしめ得た. この成績は Solimann \& Reineke $(1955)^{68)}$ 及び山口 $(1957)^{1)}$ が去勢後 2 週を経た雌ラットに estrogen を投与した成績とよく合致すると云 える。即ち去勢雙ラットに対して estrogen はその投与量，去勢期間の如何に拘らず，去勢に依つて低下し た $\mathrm{I}^{131}$ 摂取率を正常の值又はそれ以上に増加せしめるものと解せられる. 去勢雄ラットでは estrogen 全量 $5 \mathrm{mg}$ 投与群に於ては明らかな変化はなく，全量 $5 \gamma$ 投与群では甲状腺 $\mathrm{I}^{131}$ 掑取率は明らかな增加を示した。 一方血清 $\mathrm{I}^{131}$ の PBI 転換率は雌ラットでは Desclin $(1951)^{64)}$ ，山口 (1957) ${ }^{1)}$ の成績と同じく，刘照群と の間に明らかな差異を認め得ない. 雄ラットでは estrogen 全量 $5 \gamma$ 投与群に於て有意の増加を認めた. この 事春は第 2 章で去勢後 2 週を経た雄ラットに estrogen を投与し，全群に血清 $\mathrm{I}^{131}$ の PBI 転換率の増加を 来たした成績とよく符合すると云える。 上述の所見から estrogen は去勢雌ラットに対しては甲状腺での沃 度捕促能力を促進し，去勢雄ラットに対しては甲状腺ホルモン放出過程に促進的に作用するすのと考えられ る.

以上の事実から性腺を剔除して長期間を経た場合に於ても，尚且，estrogen が雌雄ラットの甲状腺に対 して夫々異つた反応を示すととは，甲状腺の estrogen に対する親和性が性によつて異なるものと解せざる を得ない，乙の事は臨床上甲状腺疾患が何故女性に多発するかの本態を究明するに当り有力な示唆を与える ものと云えよう。

\section{3. progesterone 投与に就いて}

progesterone の甲状腺に及ばす影響に就いても estrogen と同じく，諸家により種々と研究されて来たが 未だ一致した結論を得ていない. Schilling \& Laqueur $(1941)^{42)}$ は雌ラットに progesterone を投与し甲状腺 


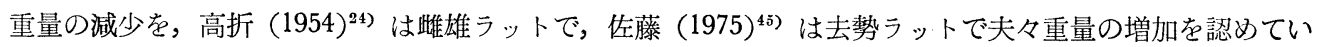
る。私は去勢後 2 カ月を経た倠雄ラットに progesterone 全量 $25 \mathrm{mg} ， 250 \gamma$ を投与したが甲状腺重量は対照 群に比し明らかな变化を認め得ない，即ち私の用いた量及び期間では甲状腺重量は影響を受けないと云いう

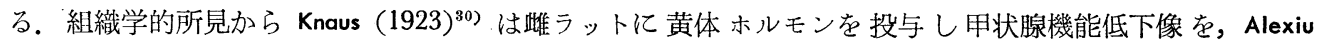

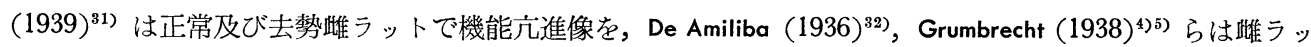
トで夫々甲状腺組織は影響を受けないと報じ，高折 (1954) ${ }^{24)}$ は雙雄ラットで progesterone の短期間投与 は膠様甲状腺腫像を，長期投与では実質性甲状腺腫像を認めたと述へている。私は去勢後 2 力月を経た雌雄 ラットに progesterone を1日 $5 \mathrm{mg} ， 50 \gamma$ を各々 5 日間投与したが甲状腺の組織学的所見は対照群と比較し て著変を認め得ない．即ち私の用いた量及び期間では De Amiliba $\left.(1936)^{32}\right)$, Grumbrecht $(1938)^{4) j)}$ らの所 見と同じく progesterone は甲状腺組織に無影響であると解せられる.

$I^{131}$ を用いた実験では鈴木 $(1957)^{69)}$ は去勢婦人に progesterone（1 日10 mg，5 日間）を投与し，甲状 腺 $\mathrm{I}^{131}$ 掑取率の減少を，Zingg（1953) ${ }^{27)}$ らは男子に progesterone（1 日25mg，6日間）を投与し，甲状腺

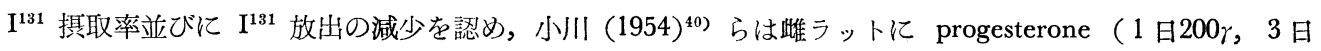
間）を投与し $\mathrm{I}^{131}$ 椇取率の減少を来たすとし，林 (1955) $\left.{ }^{46}\right)$ らは雌ラットに progesterone 1 日 $1 \mathrm{mg} ８$ 日間投与により甲状腺 $\mathbf{I}^{131}$ 摄取率は減少傾向を示したと報告している. 次に去勢動物に progesterone を投 与した成績では佐藤 $(1957)^{45)}$ は去勢雌ラットに progesterone $0.5 \mathrm{mg}$ を隔日に 30 日間投与し， $\mathrm{I}^{131}$ 掑取率の 減少を認め, Soliman \& Reineke $(1955)^{68}$ ) は去勢雌ラットに progesterone 0.2 及び $0.4 \mathrm{mg}$ 投与では甲状 腺 $\mathrm{I}^{131}$ 摄取率の減少傾向を, $0.8 \mathrm{mg}$ では逆偪加する傾向を認め, 又, estrogen 前処置後に progesterone 0.4 又は $0.5 \mathrm{mg}$ した時には增加した $\mathrm{I}^{131}$ 掑取率を対照の值迄に低下せしめ得たと報告している.

私は去勢後 2 カ月を経, 甲状腺機能が低下した雌雄ラットに, progesterone を1 日 $5 \mathrm{mg}, 50$ をを々 5 日間投与し， $I^{131}$ を以つて甲状腺えの影響を検討した処，雌ラットでは甲状腺 $\mathrm{I}^{131}$ 摄取率は全量 $25 \mathrm{mg}$ 投与 群に於て明らかな増加を示したが，全量250r投与群では著変は認められなかつた。雄では両投与群共甲状腺 $I^{131}$ 撕取率は刘照群に比し著変は認められない，一方血清 $I^{131}$ の PBI 転換率は雌雄ラット共対照群に比し 著明な差異は認得なかつた。 即ち $I^{131}$ を用いた私の成續からみて，その投与量，投与期間に関する限り， progesterone は去勢後 2 力月を経た雌雄ラット甲状腺に対して左程著明な影響を及ばさないと考えられる。 去勢後 2 週を経，甲状腺機能の低下した雌ラットに progesterone を投与して得た山口 (1957) ${ }^{1)}$ の成績之 私の得た睢ラットの成績を考え併せ， progesterone は去勢期間の長短に拘らず雌ラットの甲状腺に対して組 織学的にも，又，機能的にも明らかな作用を及ばさないと云いうる．然し乍ら雄ラットでは第 2 章で去勢後 2 週を経たラットに progesterone を投与し，その際甲状腺 $I^{131}$ 掑取率の著明な減少を来たしたに反し，2 カ月では著変を認め得なかつた。 即ちこの事実は去勢期間の長短により progesterone の雄ラット甲状腺に 及ばす反応効果が異なるものと解せざるを得ない。

\section{4. androgen 投与に就いて}

androgen 投与時の甲状腺機能を研究した従来の業績をみると，先づ甲状腺重量並びに組織学的所見加ら 斉藤 $(1930)^{11)}$ は去勢家鬼に闰丸物質を投与して甲状腺重量'の減少を認め，Leathem (1951) ${ }^{36)}$ は正常及び 去勢ラットに, Conner \& Shaffner $(1954)^{70)}$ は家鶏に testosterone prop. を投与し甲状腺重量は不変である とし，山口 (1957) 1) は去勢雌ラットに testosterone prop. を投与したが，甲状腺重量並びに組織像は変化 を来たさないと述へ，Burris (1953) ${ }^{37}$ ) らは雌雄の凟に testosterone prop. を投与して甲状腺重量の増加之機 能六進像を認め，佐藤（1957) ${ }^{45}$ ) は去勢堆ラットに testosterone prop. (0.5 mg，隔日に30日間) を投与し 甲状腺重量の増加を，高折(1954) $)^{24)}$ はラットに testosterone prop. (1 日2.5mg) 15日間投与では甲状腺重 量に変化なく，30日間投与では重量の増加と組織学的に実質性甲状腺腫というべき増殖像を呈すると述へ， 土肥 $\left.(1958)^{71}\right)$ は正常ラットに testosterone の少量 $(2.5 \mathrm{mg}, 1$ 回) 投与により甲状腺重量の増加之機能六 進像を，大量（1日 $5 \mathrm{mg} ， 10$ 日間）没与では重量の減少と機能低下像を認》たと述べている。かくの如く androgen の甲状腺に及ばす影響に就いては未だ見解の一致をみていない。私は去樊後60日を経た雌雄ラッ 
トに testosterone prop. 1 日 $5 \mathrm{mg}$ 及び 50 をを夫 5 日間投与し甲状腺重量並びにその組織学的所見を検討 した処，Leathem $(1951)^{36)}$, 山口 $(1957)^{1)}$ の得た成績と同じく雌雄ラット共対照群に比し明らか変な化 を認め得なかつた. 即ち私の用いた量, 投与期間に関する限り，去勢雌雄ラットの甲状腺に対して testosterone prop. は著明な影響を及ぼさないと云いうる。

$I^{131}$ を用いた奏験では Money $(1950,1951)^{22) 23)}$ らは雄ラットに testosterone 及び testosterone prop. ( 1 日 $5 \mathrm{mg} ， 10$ 日間）を投与し $\mathrm{I}^{131}$ 摂取率の著明な增加を，高折 (1954) 24) は雄ラットに testosterone (1 日 2.5mg，31～32日間）を投与し， $\mathrm{I}^{131}$ 摂取率及び血獎 $\mathrm{I}^{131}$ の PBI 転換率は増加の傾向を示すと述べ，林 $(1955)^{46)}$ らは雌ラットに testosterone prop. (1 日 $1 \mathrm{mg}, 8$ 日間) を投与し甲状腺 $\mathrm{I}^{131}$ 摂取率の減少を， 佐藤 $\left.(1957)^{45}\right)$ は去勢雌ラットに testosterone prop. (0.5mg 隔日，30日間）を投与して甲状腺 $\mathrm{I}^{131}$ 摂取率 の低下を認め，尚 methylthiouracil による甲状腺肥大も testosterone prop. 投与により抑制されると述べ ている. Brown-Grant $(1955)^{72)}$ は家鬼で testosterone prop. 投与が $I^{131}$ label thyroxine の放出に無影響で あるとし。 Kochakian \& Evans $(1956)^{18)}$ は正常，去勢ラットの甲状腺 $\mathrm{I}^{131}$ 掑取率及び $\mathrm{I}^{131}$ の甲状腺からの 放屾は testosterone prop. (1 日1 mg，38日間）投与により影響を受けないとしている。山口 (1957) ${ }^{1)}$ 去勢雌ラットに testosterone prop. (1 日 $5 \mathrm{mg}, 0.5 \mathrm{mg} ， 50 \gamma ， 4 \sim 5$ 日間) を投与し， I ${ }^{131}$ 摂取率には著 変ないが。血清 $\mathrm{I}^{131}$ の PBI 転換率は全量 $20 \mathrm{mg} ， 2.5 \mathrm{mg}$ 投与群では明らかに低下するとし，去勢倠うット

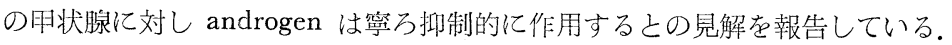

私は去勢後60日を経た踓雄ラットに testosterone prop. (1 日 $5 \mathrm{mg} ， 50 \gamma ， 5$ 日間) を投与し， I ${ }^{131}$ を用い て甲状腺機能を検索した処，雌ラットに於ては testosterone prop. 全量 $25 \mathrm{mg}$ 投与群に於て I ${ }^{131}$ 掑取率の著 明な減少を認めた。 この成績から androgen の大量投与は土勢後 2 力月を経た踓ラット甲状腺機能に対し 抑制的に作用するものと解せられ，去勢後 2 週を経た踓ラット甲状腺に対し androgen が抑制的に作用する という山! (1957) ${ }^{1)}$ の見解とよく一致する。一方雄ラットでは既に第 2 章で去勢後 2 遄のラットに投与し て得た成績之同様に， androgen は去勢後 2 力月在経た雄ラットの用状腺に刘しても明らかな变化を及代さ ない之考えられる，即ち以上の事垁から雄ラットの明状腺はこの性腺の制約を殆んど受けていないと解せら れる。

\section{第4章 結 語}

去勢後60日を経た雌雄ラット立びにこれい名種性ホルモン（estrogen，progesterone，及び androgen)を投 与した場合の甲状腺機能を $I^{131}$ を用いて検索し，次の如き結果を得た。

1）去勢に依る成績

甲状腺 $\mathrm{I}^{131}$ 摂取率は正常無処犆群に比して雌ラットでは有意の減少を示し，雄では減少の傾向を示すが有 意の変化はない. 血清 $\mathrm{I}^{131}$ の $\mathrm{PBI}$ 転換率は正常無処置群に比し雌雄ラット共変化を認めない. 甲状腺重量 は雌雄共变化はなく，甲状腺の組織学的所見は雌雄ラット共に機能低下像を呈した。

2) estrogen 投与成績

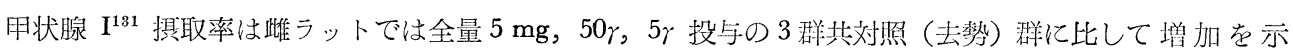
し，雄では全量 $5 \gamma$ 投与群に於て增加を，全量 $5 \mathrm{mg}$ 投与群では变化はない. 血清 $\mathrm{I}^{131}$ の PBI 転換率は 雌では投与 3 群共変化なく，雄では全量 $5 \gamma$ 投与群に於てのみ增加を示した。

3) progesterone 投与成績

甲状腺 $I^{131}$ 掑取率は雌ラットでは全量 $25 \mathrm{mg}$ 投与群に於て增加を示し，全量 $250 \gamma$ 投与群では変化はない. 雄では投与 2 群共変化を認めない. 血清 $\mathrm{I}^{131}$ の PBI 転換率は雌雄共に対照（去樊）群と比較して変化を認 むない.

4) androgen 投与成績

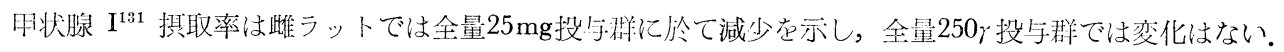
雄では投与. 2 群共变化を認めない. 血清 $\mathrm{I}^{131}$ の PBI 転換率は雌雄共対照（去勢）群に比して変化を認めな 认. 
5) estrogen, progesterone. androgen 投与時の甲状腺重量及び甲状腺の組織学的所見は雌雄ラット共対 照（去勢）群に比し著明な変化は認められない。

6) 以上の実験成績から,去勢後 60 日を経た雌雄ラットの甲状腺は組織学的にも又， I ${ }^{131}$ 摂取率の所見から みても両者共機能低下を来たすが，その低下の度は雄に比し雌の方が著明であると解せられる。去勢雌ラッ トでは estrogen 投与量の大小に拘らず，甲状腺 $\mathrm{I}^{131}$ 掑取率を著明に増加せしめ得たてとから， estrogen は雙ラットに対しては甲状腺での沃度捕促に関し促進的に作用し，てれに反し，雄ラットに対しては血中へ の甲状腺ホルモン放出に当つて促進的任作用するあのと考元られる。 又， androgen 投与が去勢雄ラット甲 状腺に明らかな影響を及ばさないことから，雄ラットの甲状腺は性腺の制約を殆んど受けてないものと思わ れる。

\section{第 4 章 去勢ラットに性ホルモン投与時の甲状腺に対する TSH の影響 並びに下垂体剔除ラットに estogen 投与時の甲状腺機能}

\section{第 1 節 まえがき}

第 1 章で成熟雄ラットを去勢すると，去勢後 42 日以後に於て甲状腺機能が低下する傾向にあることを知り 得たが，乙の去勢依る甲状腺機能低下が甲状腺刺㦸示ルモン（以下 TSH と略記す）投与に依つて如何な る反応を示すむのか，TSH 亿対する感受性は如何なるすのであらうか．即ち去勢に依る甲状腺機能低下が 一次的なむのか，或は中枢的即ち下垂体を関与するものであるかを検討するため，去勢後42日を経て甲状腺 機能の低下して雄ラットにあらかじめ, estrogen, estrogen-progesterone, androgen の前処置を加え，然る 後 TSH を投与した際の甲状腺機能えの影響を検討した。

次に下垂体の甲状腺えの支配を可及的に除去する目的で，下垂体剔除雌ラットを用い，乙れに estrogen を投与した際の甲状腺機能えの影響を検討した．以上てれらの知見を以つて性ホルモンの甲状腺刺战ホルモ ン産生への影響を間接的に検討し，性ホルモンの甲状腺に対する作用機序を解明せんと試みた。

\section{第 2 節 実験材料及び実験方法}

実験材料及び実験方法は第 1，2，3 章と同様である。尚，下垂体剔出動物には体重 120１50gm の性周 期の整調な $\mathrm{C}$ 系成熟雌ラット並びに生後22日の㭃若 C 系雌ラットを用いた。 TSH は Schering 社の Pretiron を用い，それを正常群及び去勢後42日を経た対照群及び去勢後42日を経，estrogen，estrogen-progesterone， 及び androgen で夫々前処置した4群住対して 1 日, 1 回, 10 J.S. (Junckmann-Schoeller) 単位を4日間皮下 注射した。各群は最後の TSH 投与と同時に $\mathrm{I}^{131} 20 \mu \mathrm{c}$ を tracer として投与し， 24 時間後に心臟穿刺によ り採血致死せしめた。 下垂体剔出は小山 $\left.(1930)^{73}\right)$ の外聴道変法による田中法 $(1955)^{74)}$ により剔出を行い， 下垂体剔出後は $25^{\circ} \mathrm{C}$ 前後の静かな部屋に飼育管理し成熟ラットでは下垂体剔出後 7 日目より，幼若ラットで は20日目より夫々 estrogen を 2 日間投与し，致死せしもる24時間前に $\mathrm{I}^{131} 20 \mu \mathrm{C}$ を投与した，尚，実駼終 了後剖検により下垂体残存の有無を確認し，不正確なものはてれを実験成績より除外した。

\section{第 3 節 実験成綪}

\section{第 1 項 去勢雄ラットに性ホルモン前処置後 TSH 投与成績}

1. 去勢雄ラットに TSH 投与成績

1) 甲状腺 $\mathrm{I}^{131}$ 摂取率（第 5 表, 第 8 図)

去勢しない雄ラットに TSH を投与した正常無処置群に比して明らかな変化はない.

2) 血清 $I^{131}$ のPBI 転換率（第 5 表，第 8 図）

去勢しない雄ラットに TSH を投与した正常無処置群に比して有意の変化を認めない.

3) 甲状腺重量及び組織学的所見（第 5 表，附図(9)

去勢しない雄ラットに TSH を投与した正常無処置群に比し甲状腺重量及び組織学的所見は共に明らかな 差異を認やない. 
4) 下垂体重量 (第 5 表)

去勢しない雄ラットに TSH を投与した正常無処置群に比し, 著明な減少を示した.

第 5 表 去勢後 42 日目に性ホルモン前処置後 $\mathrm{T} \mathrm{S} \mathrm{H}$ 投与時の計測平均值

\begin{tabular}{|c|c|c|c|c|c|c|c|c|c|c|c|c|}
\hline \multirow[b]{2}{*}{ 令 } & \multicolumn{2}{|c|}{ 投与日数 } & \multicolumn{2}{|c|}{1 日投与量 } & \multirow{2}{*}{$\begin{array}{l}\text { 動 } \\
\text { 物 } \\
\text { 数 }\end{array}$} & \multirow{2}{*}{$\begin{array}{l}\text { 終 } \\
\text { 体 } \\
\text { 重g }\end{array}$} & \multicolumn{2}{|c|}{ 甲 } & \multirow{2}{*}{\begin{tabular}{|l|}
\multicolumn{1}{|c|}{ 腺 } \\
$\begin{array}{l}I^{131} \\
\text { 摄取率 } \\
(\%)\end{array}$ \\
\end{tabular}} & \multirow{2}{*}{\begin{tabular}{|c} 
血 清 \\
P B I \\
$\begin{array}{c}\text { 転換率 } \\
(\%)\end{array}$
\end{tabular}} & \multicolumn{2}{|c|}{ 脳下垂体 } \\
\hline & $\mathrm{TSH}$ & $\begin{array}{l}\text { 性木 } \\
\text { ル } \\
\text { モ } \\
\text { ン } \\
\end{array}$ & $\begin{array}{c}\text { TSH } \\
\text { (J.S.U.) }\end{array}$ & $\begin{array}{r}\text { 性木 } \\
\text { J } \\
モ \\
\text { Z }\end{array}$ & & & $\begin{array}{l}\text { 重量 } \\
\text { (mg) }\end{array}$ & $\left|\begin{array}{l}\text { 体重 } 100 \mathrm{~g} \\
\text { 当の重 } \\
\text { 量 (mg) }\end{array}\right|$ & & & $\frac{\text { 重量 }}{(\mathrm{mg})}$ & $\begin{array}{l}\text { 体重 } 100 \mathrm{~g} \\
\text { 当の重 } \\
\text { 量 (mg) }\end{array}$ \\
\hline 正常無処置 & 4 & 5 & 10 & $\left|\begin{array}{c}\Delta \\
0.5 c c\end{array}\right|$ & 3 & 140.6 & 16.5 & $\left|\begin{array}{c}8.52 \pm \\
0.21\end{array}\right|$ & $\left|\begin{array}{r}28.84 \pm \\
0.98\end{array}\right|$ & $\begin{array}{r}13.85 \pm \\
2.75\end{array}$ & 4.3 & $\begin{array}{c}3.25 \pm \\
0.19 *\end{array}$ \\
\hline 対照 (去勢) & 4 & 5 & 10 & $0.5 \mathrm{cc}$ & 4 & 144.3 & 19.0 & $\left|\begin{array}{r}7.59 \pm \\
1.02\end{array}\right|$ & $\mid \begin{array}{r}25.57 \pm \\
1.22\end{array}$ & $\begin{array}{r}15.71 \pm \\
1.98\end{array}$ & 6.8 & $\begin{array}{r}1.83 \pm \\
0.42\end{array}$ \\
\hline $\begin{array}{l}\text { est. benz. } \\
5 \gamma+\text { TSH }\end{array}$ & 4 & 5 & 10 & $1 \gamma$ & 4 & 164.0 & 21.5 & $\begin{array}{r}7.63 \pm \\
0.60\end{array}$ & $\mid \begin{array}{c}33.39 \pm \\
1.46^{* *}\end{array}$ & \begin{tabular}{|}
$94.26 \pm$ \\
$3.61^{* * *}$
\end{tabular} & 7.3 & $\begin{array}{r}2.24 \pm \\
0.57\end{array}$ \\
\hline $\begin{array}{c}\text { E.P. } 50 \gamma: \\
\text { 2.5mg + TSH }\end{array}$ & 4 & 5 & 10 & $\begin{array}{l}10 \gamma: \\
0.5 \mathrm{mg}\end{array}$ & 3 & 145.0 & 17.5 & $\left|\begin{array}{c}8.28 \pm \\
1.25\end{array}\right|$ & $\begin{array}{r}25.80_{ \pm} \\
1.08\end{array}$ & $\mid \begin{array}{c}77.37 \pm \\
2.25^{* *}\end{array}$ & 7.4 & $\begin{array}{r}1.95 \pm \\
0.09\end{array}$ \\
\hline $\begin{array}{l}\text { test. prop. } \\
25 \mathrm{mg}+\mathrm{TSH}\end{array}$ & 4 & 5 & 10 & $5 \mathrm{mg}$ & 3 & 171.6 & 19.5 & $\begin{array}{r}8.80 \pm \\
0.90\end{array}$ & $\left|\begin{array}{c}37.22 \pm \\
2.04^{* *}\end{array}\right|$ & $\mid \begin{array}{c}77.73 \pm \\
3.28^{* * *}\end{array}$ & 7.0 & $\begin{array}{r}2.44 \pm \\
0.72\end{array}$ \\
\hline $\begin{array}{l}\text { test. prop. } \\
100 \gamma+\mathrm{TSH}\end{array}$ & 4 & 5 & 10 & $20 \gamma$ & 3 & 153.3 & 19.6 & $\left|\begin{array}{r}7.82 \pm \\
1.80\end{array}\right|$ & $\begin{array}{r}28.63 \pm \\
1.90\end{array} \mid$ & $\left|\begin{array}{r}17.53 \pm \\
0.74\end{array}\right|$ & 7.0 & $\begin{array}{r}2.21 \pm \\
0.33\end{array}$ \\
\hline
\end{tabular}

有意差は各計測平均值を対照のそれと比較したものである

* $\mathrm{P}<0.05 *$ * $\mathrm{P}<0.01$ 土平均誤差を示す $\triangle$ 精製胡麻油のみ

第 8 図去勢後 42 日目に性ホルモン前処置後 $T S H$ 投与時の甲状腺機能

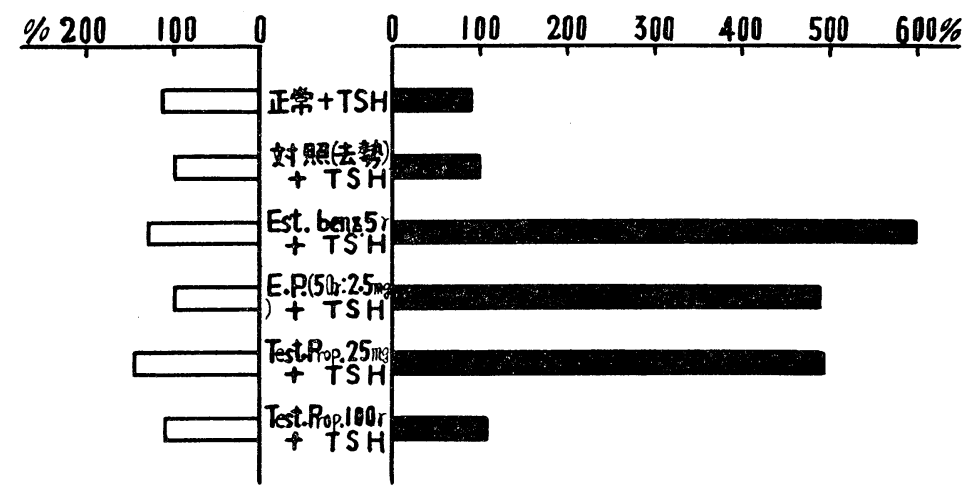

甲状腺 $\mathbf{I}^{131}$ 摂取率

血清 $\mathrm{I}^{131}$ の PBI 転換率

2. estrogen の前処置後 TSH 投与成績

1) 甲状腺 $\mathrm{I}^{131}$ 摂取率（第 5 表，第 8 図）

去勢ラットに TSH のみを投与した対照群に比して有意の増加を示した。

2) 血清 $\mathrm{I}^{131}$ の PBI 転換率（第 5 表，第 8 図）

対照群に比し明らかな増加を示した。

3) 甲状腺重量及び組織学的所見（第 5 表，附図(10)

甲状腺重量は対照群と変化はない. 組織所見は. TSH のみを投与した刘照群に比し小型濾胞の増加，濾胞 上皮細胞の肥大，乳嘴状増殖が著明である。 
4) 下垂体重量（第 5 表）

対照群に比し著変を認めない。

3. estrogen-progesterone の前処置後 TSH 投与成績（第 5 表，第 8 図）

1) 甲状腺 $\mathrm{I}^{131}$ 摂取率 (第 5 表, 第 8 図)

刘照群に比して明らかな変化はない.

2) 血清 $I^{131}$ のPBI 転換率 (第 5 表, 第 8 図)

対照群に比し有意の増加を示した。

3) 甲状腺重量及び組織学的所見（第 5 表，附図(11)

甲状腺重量は対照群に比し明らかな変化はない，組織学的所見は estrogen 前処置群よりも機能低下像を 呈した。

4) 下垂体重量（第 5 表）

対照群に比して著明な変化はない。

4. androgen の前処置後 TSH 投与成績

1) 甲状腺 $I^{131}$ 掑取率 (第 5 表, 第 8 図)

全量 $25 \mathrm{mg}$ 投与群では対照群に比し有意の増加を示し，全量 100 亿投与群では明らかな変化はない.

2）血清 $\mathrm{I}^{131}$ のPBI 転換率（第 5 表，第 8 図）

全量 $25 \mathrm{mg}$ 投与群では対照群に比し明らかに増加を示し，全量 $100 \gamma$ 投与群では変化はない.

3) 甲状腺重量及び組織学的所見（第 5 表，附図(12)

甲状腺重量は投与 2 群共対照群に比し著変を認めない。組織学的に全量 $25 \mathrm{mg}$ 投与群では estrogen $+\mathrm{TSH}$ 投与群に比し濾胞上皮細胞の肥大強く，分泌空胞の形成及び乳嘴状增殖が著明である．全量100个投与群では $25 \mathrm{mg}$ 投与群に比し上皮細胞の肥大は軽度で且, 分泌空胞の形成も少ない.

4) 下垂体重量 (第 5 表)

投与 2 群共対照群に比し明らかな変化は認めない.

\section{第 2 項 下垂体剔除䊒ラットに estrogen 投与成績}

1。下垂体剔除成熟雌亏ットに estrogen 投与成繶

1) 甲状腺 $I^{131}$ 摂取率 (第 6 表, 第 9 図)

投与 2 群共胡麻油のみを投与した垂剔対照群に比し，著明な增加を示した。

2) 血清 $\mathrm{I}^{131}$ のPBI 転換率 (第 6 表, 第 9 図)

投与 2 群共対照群に比し明らかな増加を示した.

3) 甲状腺重量及び組織学的所見（第 6 表，附図 77，8）重量並びに組織学的所見は共に垂剔対照群に比 して明らかな差異は認めない。

第 6 表 脳下垂体剔除ラットに性ホルモン投与時の計測平均值

\begin{tabular}{|c|c|c|c|c|c|c|c|c|c|c|c|}
\hline & & \multirow{2}{*}{ 우 } & \multirow{2}{*}{$\begin{array}{l}\text { 垂 } \\
\text { 剔 } \\
\text { 日 } \\
\text { 数 }\end{array}$} & \multirow{2}{*}{$\begin{array}{l}\text { 投 } \\
\text { 与 } \\
\text { 日 } \\
\text { 数 }\end{array}$} & \multirow{2}{*}{$\begin{array}{r}\text { 一投 } \\
\text { 与 } \\
\text { 日量 }\end{array}$} & \multirow{2}{*}{$\begin{array}{l}\text { 動 } \\
\text { 物 } \\
\text { 数 }\end{array}$} & \multirow{2}{*}{$\mid \begin{array}{l}\text { 終体重 } \\
(\mathrm{g})\end{array}$} & \multicolumn{2}{|r|}{ 甲 } & 腺 & \multirow{2}{*}{$\frac{\text { 血 清 }}{\text { P B I 転換率 }}$} \\
\hline & & & & & & & & $\begin{array}{c}\text { 重量 } \\
\text { (mg) }\end{array}$ & $\left|\begin{array}{l}\text { 体重 } 100 \mathrm{~g} \text { 当 } \\
\text { の重量 }(\mathrm{mg})\end{array}\right|$ & $\begin{array}{c}\mathrm{I}^{131} \text { 摂取率 } \\
(\%)\end{array}$ & \\
\hline \multirow{3}{*}{$\mathrm{I}$} & 成 & 対照(垂剔のみ) & 7 & 2 & $0.5 \mathrm{cc} \triangle$ & 3 & 125.6 & 11.20 & $|11.21 \pm 1.63|$ & $4.76 \pm 0.23$ & \multirow{3}{*}{$\begin{array}{l}16.33 \pm 1.08 \\
23.90 \pm 2.14^{* *} \\
25.66 \pm 0.76^{*}\end{array}$} \\
\hline & 熟 & estrogen $200 \gamma$ & 7 & 2 & $100 \gamma$ & 3 & 132.8 & 11.39 & $11.65 \pm 0.44$ & $10.17 \pm 0.49 * *$ & \\
\hline & 群 & estrogen $20 \gamma$ & 7 & 2 & $10 \gamma$ & 3 & 126.3 & 11.03 & $11.45 \pm 2.00$ & $10.38 \pm 0.92^{* *}$ & \\
\hline \multirow[b]{2}{*}{ II } & 幼 & 対照(垂剔のみ) & 20 & 2 & $0.5 \mathrm{cc} \triangle$ & 3 & 38.5 & 4.75 & $8.11 \pm 0.71$ & $1.50 \pm 0.02$ & \multirow{2}{*}{$\begin{array}{l}14.22 \pm 2.01 \\
58.81 \pm 3.32^{*}\end{array}$} \\
\hline & $\begin{array}{l}\text { 若 } \\
\text { 群 }\end{array}$ & estrogen $20 \gamma$ & 20 & 2 & $10 \gamma$ & 3 & 37.0 & 4.65 & $7.96 \pm 0.93$ & $6.53 \pm 0.34^{* *}$ & \\
\hline
\end{tabular}

有意差は各計測平均值を対照のそれと比較したものである

** $\mathrm{P}<0.01$ 土平均誤差を示守 $\triangle$ 精製胡麻油のみ 
第 9 図 下垂体剔除ラットに Estrogen 投与時の甲状腺機能

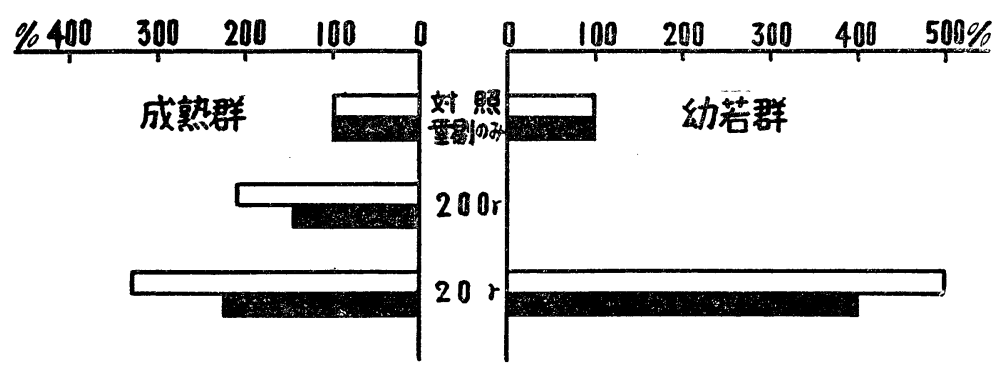

甲状腺 $\mathrm{I}^{131}$ 摂取率血清 $\mathrm{I}^{131}$ の PBI 転換率

2。下画体剔除纱若雌ラットに estrogen 投与成績

1) 甲状腺 $\mathrm{I}^{131}$ 摂取率（第 6 表，符 9 図）

胡麻油のみを投与した対照群に比し有意の增加宣示した。

2) 血清 $I^{131}$ のPBI 転換率（第 6 表，第 9 図）

対照群に比して有意の増加を示した。

3) 甲状腺重量及び組織学的所見 (第 6 表)

重量及び組織所見は共に対照群に比して明らかな変化は認むない。

\section{第 4 節 総括並びに考按}

私は正常及び去勢後42日を経た雄ラットに TSH を投与し。甲状腺機能えの影響を I ${ }^{131}$ を以つて梌討し た処，甲状腺 $\mathrm{I}^{131}$ 掑取率並びに血清 $\mathrm{I}^{131}$ の PBI 転換率共に両者の間に明らかな变化はなく，又，甲状腚 の組織学的所見からあ両者の間に明らかな差異を認わないととから，去勢雄ラットの甲状腺はTSH に対し て正常ラット之同様の反応を営むもの之考元られる。乙の事は去勢睢ラットに TSH を投与し，先の反応加 ら去勢雌ラットの里状腺は TSH に対する感受性の低下，特に学の metabolic effect が低下しているとす る山口 $(1957)^{1)}$ の成績とは全く相反する所見である。即ち去勢した場合，TSH に刘する甲状腺の反応は 雌雄ラットに依つて著るしい差異があり，茲にも性差の存在する事実が確められた。

次各種性ホルモン前処置後に TSH を投与した成績に就いて考察してみると，先づ estrogen を前処蜀 した場合はTSH を単独に投与した対照群に比し，甲状腺 $\mathrm{I}^{131}$ 掑取率並びに血清 $\mathrm{I}^{191}$ の PBI 転換率は著 明な増加を示し，組織学的にあ対照群に比し機能六進像を認》得たが，この事実は第 3 章で去勢後 60 日を経 た雄ラットに estrogen $5 \gamma$ 単独に投与して得た成績とよく符合し, estrogen そのあのの作用の他に TSH の作用が相乗してか〉る所見を呈したものと考元られる。 次化 E.P. ホルモン (estradiol benz. $50 \gamma+$ progesterone 2.5mg）を前処置した場合は甲状腺 ${ }^{131}$ 摄取率には変化なく，血清 $\mathrm{I}^{131}$ のPBI 転換率は刘娊 群に比し有意の増加を示したが, estrogen 前処置群に比するとその值は稍々低い. この事実は progesterone が estrogen 之拮抗的に作用し，甲状腺汶対し抑制的に作用したもの之考元られる。 又，乙の事は組織学的 にも estrogen + TSH 投与群よりも機能充進像が軽度である事からも推測に難くない. 山口 $(1957)^{1)}$ が去 勢雌ラットに estrogen を単独に前処置した後ＴSH を投与した時には $\mathrm{I}^{131}$ 掑取率は正常值过回復する が，血清 $\mathrm{I}^{131}$ の PBI 転換率は增加せず progesterone を添加するととにより血清 $\mathrm{I}^{131}$ のPBI 転換率を正 常值迄上昇せしめ得たという成績と比較してみると，E.P. ホルモン前処置に依る甲状腺機能えの影響は 雌雄ラットに依つて可成り異つた反応を示すむのと解せられる。次に androgen を前処置した場合は。 testosterone prop. 全量 $25 \mathrm{mg}$ 投与群では $\mathrm{I}^{131}$ 掑取率並びに血清 $\mathrm{I}^{131}$ の PBI 転換率は共に著明な增加を来

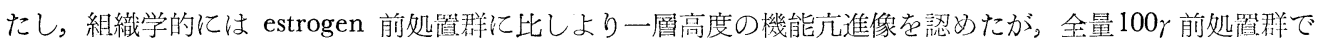

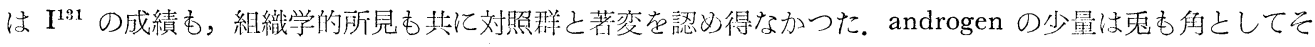


の大量は組織学的に estrogen 前処置群より高度の機能立進像を示した事実は, 松本 (1959) $\left.{ }^{75}\right)$ が LipschulzBiskind の手術を施した雌ラットに androgen を投与し，その田状腺所見から androgen は主として tropic factor としての作用を有するとの見解と類似しており，私も androgen の大量は tropic factor として作用 する可能性がある屯のと推定したい.

扱て性ホルモンの甲状腺機能に及ぼす作用機序に就いては徒来より下垂体仲介説と甲状腺直接作用説とが あり，未だその州趋は明らかでない，一般に estrogen は下垂体を介して明状腺に作用するとされている

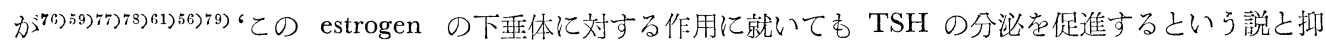

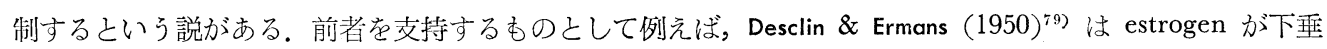
体前葉の TSH の産生, 分泌を増加させるか，或は下垂体の甲状腚刺㦸効界を促進する為であるとし，Turner \& Cupps $(1940)^{80)}$ は去勢雌ラットに estogen 在投与した場合, 下垂体に TSH 含有量の増加（BergmanTurner method) を認めたと述べ，後者を支持するすの即ち Leblond (1942) ${ }^{81)}$ らはラット下垂体前葉の甲 状腺剔出細胞出現数から estrogen は下垂体 TSH の分泌を抑制するとし，Brown-Grant (1955) ${ }^{72}$ は estrogen が甲状腺からのホルモン放出を抑制し，てれは内在性 TSH の分泌抑制の結果であらうと述べ， Lerman (1950) ${ }^{56)}$ は大量の estrogen は Gonadotropin（以下 GTH ट略記す）の産生を抑制すると共に TSH の分泌を屯抑制するとしている。一方下垂体剔出動物に estrogen を投与した成績から,高析 (1954) ${ }^{24)}$

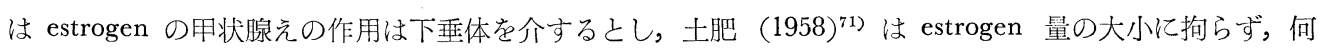
れあ下垂体を介しての作用であると述べている。

以上の如く estrogen が下垂体を介するとする説にあ，TSH 分泌の促進又は抑制の 2 説があり未だ一 定の結論に達していないが，その原因は estrogen 量及び投与期間に左右されるあのと考えられる。山本 $(1956)^{82}$ は比較的少量の estrogen は主として下垂体に作用し，TSH の分泌を高めることにより甲状腺機 能を京進させ，比較的大量の estrogen は主として直接甲状腺に作用しその機能を抑制するむのと解してい る。次に性別にみた下垂体内 TSH に就いて Turner $(1940)^{\text {s0) }}$ らは成熟ラットを去勢すると，去勢後20日で は雌雄共減少し（雌では18\%，雄では47\%)，66日では両者共更に減少し，estrogen（每日40R.U.，15〜20 日間）又は androen（毎日200\%，20日間）を投与すると，雌では正常の值迄回復するが雄では無効であると し，更に甲状腺剔出の影響として雄では40日で46\%，6力月で50\%の減少を示すのに対し，雌では40日で24 \%の増加を認めたと述べ，その性差の理由を明らかにしていない.

以上の下垂体仲介説に対して最近 $2 ， 3$ の反証が挙げられている. 即ち Braver (1950) ${ }^{43}$. らは抗甲状腺郕 に対する去勢雌ラットの甲状腺の反応から，去勢による甲状腺機能の低下は TSH の分泌減少によるもので なく，甲状腺自身の TSH に対する感受性の低下であるとし，又 Xeldman (1956) 2829) は甲状腺に対する 性ホルモンの反応は下垂体剔除ラットの甲状腺に対しても一定の影響を及ぼす事から直接甲状腺に作用ずる としている。 山口 $(1957)^{1)}$ む文，去勢ラット甲状腺に対する TSH の反応から Brauner (1950) ${ }^{43)}$ ら及び 之同様の見解を得ている，又，松本 $(1959)^{75}$ は Lipschutz-Biskind の手術を施したラットに夫々 estrogen androgen を投与した場合の脾内卵巣所見と甲状腺所見とは一致しないととから，TSH と GTH とは必 ずしも平衡して動くものでないとし，性ホルモンは直接甲状腺に作用するものと解釈している.

私は甲状腺之最む密接な関係にある estrogen を成熟，幼若下垂体剔出雌ラットに投与し，その際の唒状 腺えの影響を $\mathrm{I}^{131}$ を以つて検索した処，estrogen 投与量の大小，成幼若の如何を問わず，甲状腺 $\mathrm{I}^{131}$ 摂取 率は何れも対照に比し著明な増加を認めたてとから， estrogen は甲状腺に直接作用するすのと解せざるを 得ない. 教室の木戸 $(1958)^{83)}$ は下垂体の TSH 含有量を初生雛の甲状腺 $\mathrm{P}^{32}$ 掑取能を指標とする TSH bioassay で直接測定した成績では，去勢雌ラットに estrogen を投与し下垂体 TSH 含有量の増加を認め， estrogen に依つて甲状腺が倵活され TSH の需要が高㐫つた結果であると考えている，以上の成績よりみ て estrogen は主として直接甲状腺に作用し，中枢的作用は第二義的なむのと解される.

\section{第 5 節 結 語}

去勢雄ラット立びに去勢後 estrogen, estrogen-progesterone, 及び androgen で前処置し，然る後 TSH 第35巻 第 7 号 
を投与した場合の甲状腺機能，更に下垂体剔除雌ラットに estrogen を投与した場合の甲状腺機能に就き $\mathrm{I}^{131}$ を用いて検索し，次の如き結果を得た。

1）去勢後42日を経たラット（対照群）に TSH を投与した処，甲状腺 $I^{131}$ 摄取率，血清 $\mathrm{I}^{131}$ の PBI 転換率共に去勢しない雄ラットに TSH を投与した正常群に比し明らかな変化はない. 甲状腺重量, 甲状腺 の組織学的所見は正常群と差異を認めない. 下垂体重量は著明な減少を示した.

2) estrogen 前処置

$\mathrm{I}^{131}$ 摂取率及び血清 $\mathrm{I}^{131}$ の PBI 転換率は TSH のみ投与した対照群に比し著明な増加を示し，組織学的 にも明らかな機能克進像を示した。

3) estroged-progesterone 前処置

$\mathrm{I}^{131}$ 摄取率は対照群と変化はなく, 血清 $\mathrm{I}^{131}$ のPBI 転換率は有意の増加を示した。組織学的には estrogen 前処置群より機能低下像を示した。

4) androgen 前処置

全量 $25 \mathrm{mg}$ 投与群では $\mathrm{I}^{131}$ 摄取率及び血清 $\mathrm{I}^{131}$ のPBI 転換率は刘照群に比し有意の増加を認めたが，全 量 100 投与群では変化はない，組織学的には全量 $25 \mathrm{mg}$ 投与群では estrogen 前処员群よりも機能九推像は 一層著明であるが，全量100 投与群では軽度である。

5）成熟並びに幼若下垂体剔除雌ラットに estrogen を投与し，甲状腺 $\mathrm{I}^{131}$ 摂取率，血清 $\mathrm{I}^{131}$ の PBI 淙 換率は刘照群に比し共に明らかな増加を示した。組織学的には明らかな变化はない.

6）以上の実験結果加成熟雄ラット甲状腺は性腺の有無に拘らず，TSH 亿対して同様な反応を示すむ

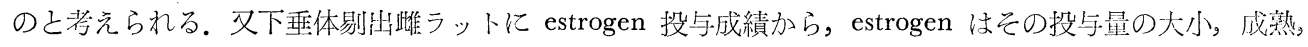
幻若ラットの如何を問わず，直接甲状腺作用するものと解せられる.

\section{全章の総括並びに結論}

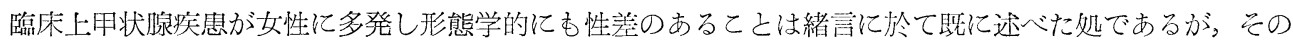
性差の由つて来たる原因並びにその本態関しては今日尚，解明の域に遠い，そてで私は雙雄成熟ラット老 用い，性差よりみた甲状腺機能の本態を究明するために $\mathrm{I}^{131}$ を以つて甲状腺と性腺との関連に就いて基整 的な一連の研究を行い注目す心゙き所見を得た。乙れらの各章て於て得られた実験成績を総括すれれ゙次の如く である.

先づ去勢に依る甲状腺機能えの影響を検討し，膗では去勢後14日，雄では42日を経るを甲状腺機能は低下 するが，その程度は雄に比し雌の方が式速に出現し且著明であるとと，又，去勢後 2 力月の長期を経た場合 に於ても尚且，甲状腺えの影響は雄に比し雌の方が著明であることを知り得た。即ち去勢依る甲状腺えの 影響がその期間の長短に拘らず，睢雄に依つて著しい差異のある事実は，甲状腺機能に明らかな性差の存在 するととを裏付けたに外ならない。

次にての性差の依つて来たる原因は当然性腺の相違に求めなくてはならないが。この機序を解明するため に, 去勢ラットに 3 種の性ホルモンを投与し甲状腺機能えの影響を検討した処，茲にも雌雄によつて可成り の反忘差のあるととを見出し得た。即ち estrogen は踓では甲状腺での沃度晎取を，雄では血中えの甲状脉 ホルモン放出に関し夫々促進的に作用すること， progesterone は雔の甲状腺には無影響であり，雄では去 勢後14日目に投与したものでは甲状腺 $\mathrm{I}^{131}$ 摂取率の減少を，2 カ月のものでは著変のないとと，又， androgen は甲状腺に対して雌雄共一定の影響を及ばさないという結果を得た。 estrogen が雙雄甲状腺亿一 定の影響を及ぼすに拘らず，androgen の作用は無影響であるといら事実からみて，estrogen が甲状腺の性 差を䓯起せしめる主因であると結論せざるを得ない。

次にての性差の主因をなす estrogen の甲状腺えの作用機序，即ち中枢性か未梢性であるかの機序を解明 するために，下垂体剔除ラットに estrogen を投与し甲状腺えの影響を検討した処，下垂体を剔除したラッ 卜に於ても estrogen 在投与すると状腺 $\mathrm{I}^{131}$ 摂取率は対照に比し著明な增加を来たした事実から, estrogen 
の甲状腺えの作用は末梢性即ち甲状腺に直接作用するものであると考元る。

結 論

1）去勢雄ラッ卜甲状腺注去勢後 42 日以後に於て機能低下を来たす。

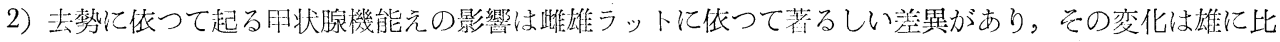
し雌の方が迅速且著明である。

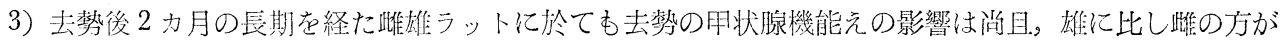
著明である。

4）各種性ホルモンの去勢ラット甲状腺に及ばす影響を総括すると， estrogen は夫々雙及び雄の用状腺機 能飞著明な影響㕝及ばすが。 androgen の作用は著明でない。

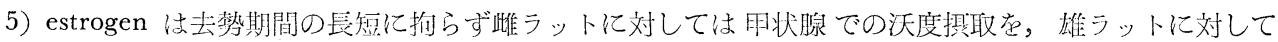
は血中元の甲状腺ホルモン放出に関し夫々促進的に作用する。 estrogen が甲状腺に対して夫々異つた反応

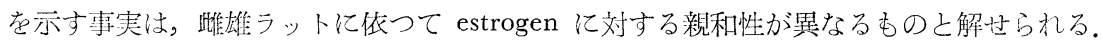

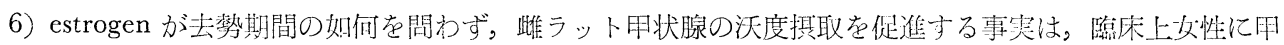
状腺疾息が多登する原因を究明するに当り，一つの有力な示朘を与える。

7）性ホルモン投与成續よりみて雌ラットの甲状腺は性腺と緊密な関係存するが。雄の甲状線怯性腺の 猘約觉然んど受けていないと解せられる。

8）雄ラット甲状腺は性腺の有無に拘らず TSH 亿対して同様の反応を示す.

9）下垂体剔除ラットに estrogen を投与した成績から，estrogen は用状腺に直接作用するもの上考无ら れる。

10）以上の諸点より甲状腺の性兴を惹起せしもる主因は estrogen であると結諭される。

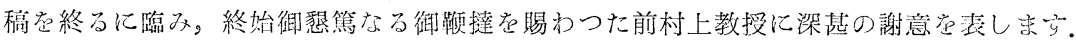

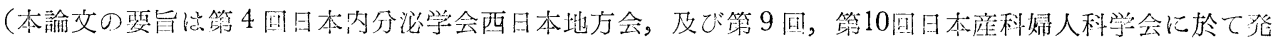
玟した。）

文献

1）山口彦司: 神戸医大紀要，9:170，1957。 2) 古関蜻夫 :オートラジオグラフイー， 1954.

3) Schultze, K.E. : Arch. f. Gynäk., $158: 746,1934 . \quad$ 4) Grumbrecht, P. \& A. Loeser : Arch. f. Exp.

Path. u. Pharmakol., $189: 345$, 1938. ((12)より引用) 5 5) Grumbrecht, P. \& A. Loeser : Arch. f. Gynäk., $169: 199,1938 . \quad$ 6) Andersen, E.M. \& H.S. Kennedy : J. Physiol., $79: 1,1933$.

Hatai, S. : J. exp. Zool. 18 : 1, 1915. ((6) より引用) 8) Mercier-Parot, L. : Bull. Microscop. Appl., $2: 117$, 1952. (Biol. Abst., $27: 1818,1952$.$) \quad 9) Livingston, A.E. : Amer. J. Physiol., 40: 153$, 1916. 10) Breneman, W.R. \& R.C. Mason : Endocrinol., $48: 752,1951 . \quad 11)$ 斎藤隆: 日本内 分䎵学会雑誌，5：335，1930. 12) Kippen, A.A. \& L. Loeb : Endocrinol., $20: 201,1936$.

Chouke, K.S. : Endocrinol., $12: 14,1930 . \quad 14)$ Crepax, P. : Arch. Sci. Biol., $35: 599,1951$ a (Biol. Abst., 28 : 579, 1954.)

15) Mercier-Parot, L. \& H. Tuchmann-Duplessis : C. r. Soc. Biol., $145: 1883$, 1951. (Ber., $158: 251$, 1953.)

16) Aron, C. \& J. Marescaux : C. r. Soc. Biol., $146: 1388,1952$. (Excerpta $7: 349,1953$.

17) Ohida, S. : Okajimas Folia Anatomica japonica, $26: 347,1954$.

18) Kochakian, C.D. \& W.W. Evans : Endocrinol., $58: 279,1956$.

19) Engstrom, W.W. et al. : Proc. Soc. Exper. Biol. Med., 81 : 582, 1952.

20) Engstrom, W.W. \& B. Markardt : J. Clin. Endocrinol., $14: 215,1954 . \quad 21)$ Lederer, J. : Ann. Endocrinol., 14:916, 1953. (Excerpta $8: 362,1954$. 22) Morey, W.L., L. Kirschner, L. Kraintz, P. Merrill, R.W. Rawson : J. Clin. Endocrinol., $10: 1282,1950$. 


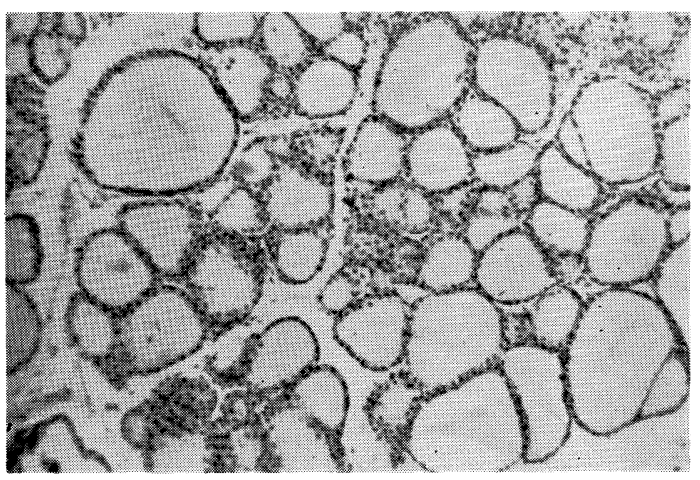

(1)附図(3)の対照

正常雄ラットの甲状腺 $($ H.E. $\times 100)$

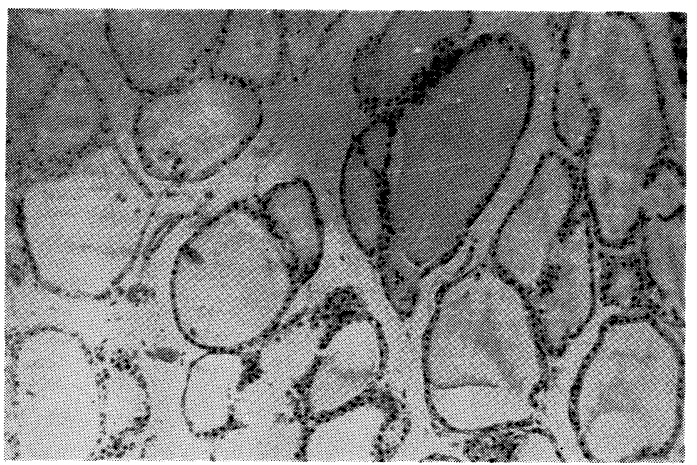

(3)去勢後 2 力月の雄ラット甲状腺 $($ H.E. $\times 100)$ 滤胞の直径法大きさを増し。滤胞上皮は扁平化 している。即方去勢甲状腺の像走示与。・

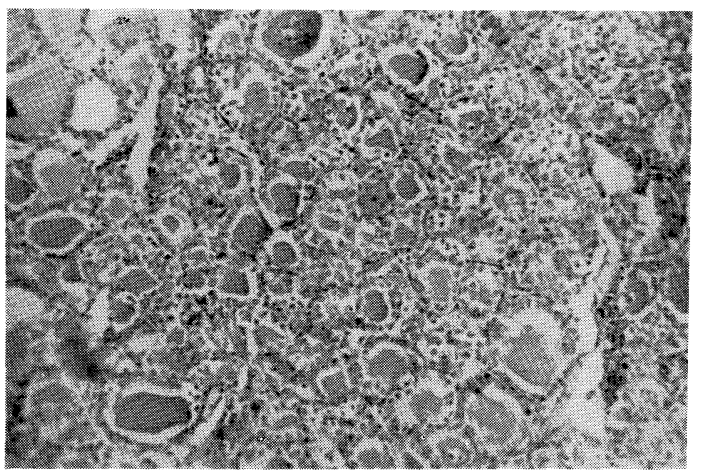

(5)去勢後14日に estradiol benzoate $5 \mathrm{mg}$ 投与し た時の雄ラット甲状腺 $($ H.E. $\times 100)$

滤胞上皮は厚径を増し濾胞の周辺部に品多数の 空胞を認める。

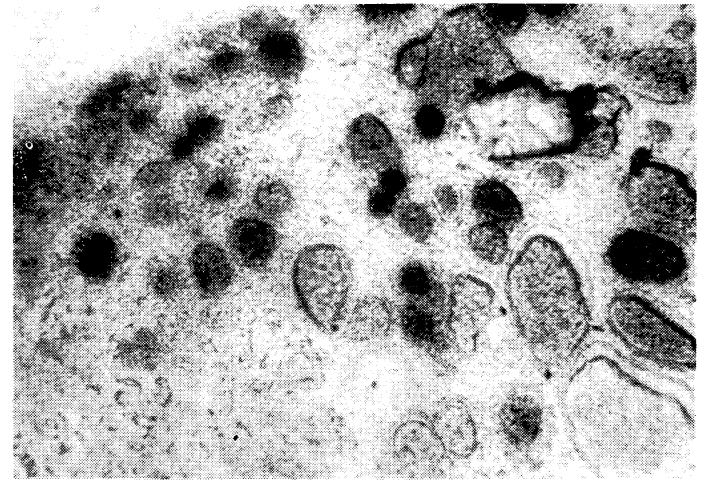

(2)附目(4)の対照

附図(1)の Radioautograph $(\times 100)$

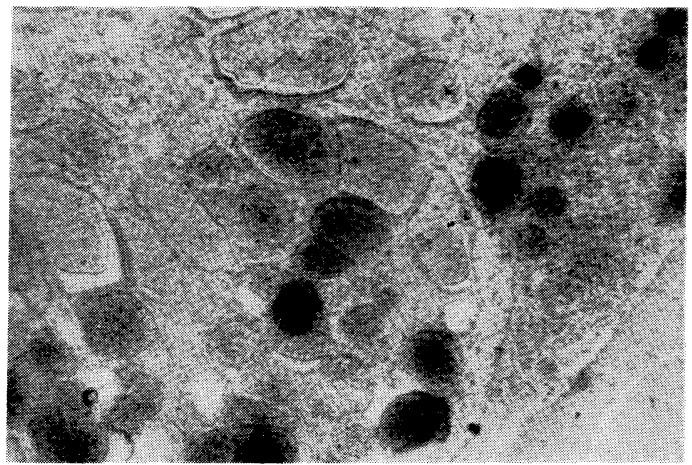

(4)附図(3)の Radioautograph $(\times 100)$

各滤胞内の $I^{191}$ の沈着は詨照(2) 亿比し少なく, autograph 像は淡くなつている.

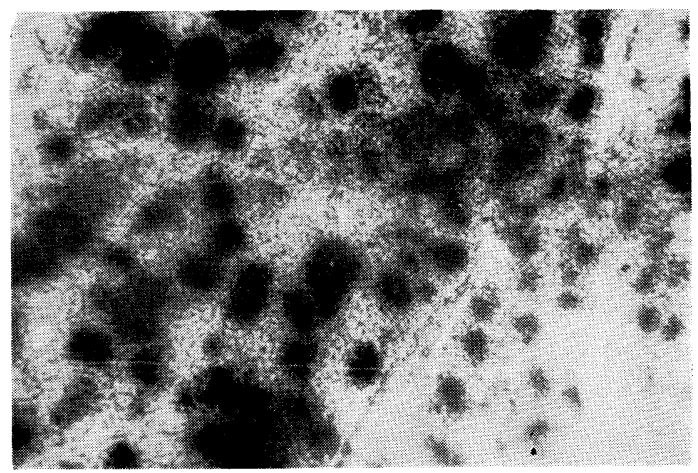

(6)附図(5) Radioautograph (H.E. $\times 100$ ) 各滤胞内に多量の $I^{131}$ の沈着が認められる。 


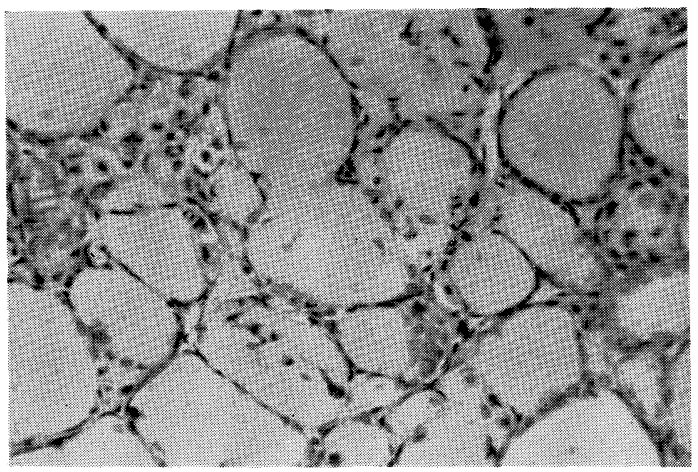

(7)附济8の対照下垂体剔出後 9 日目の雌ラツト 甲状腺 (H.E. $\times 100)$

濾胞上皮は著るしく扁平化し，一部に濾胞の融 合がみられる。

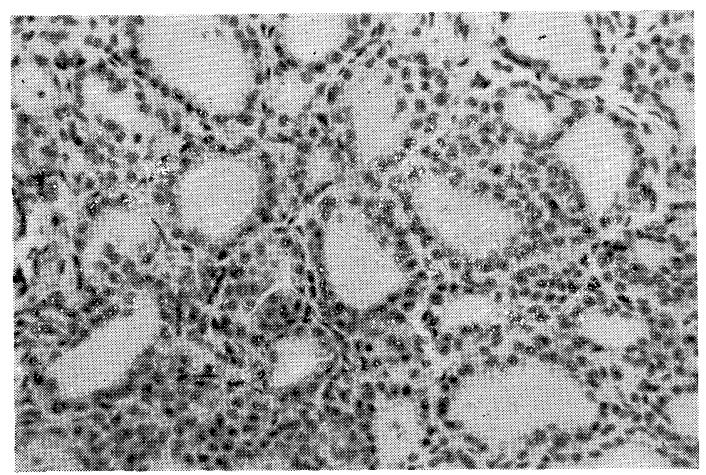

(9)附汶(10)11 (12)の対照 去勢雄ラットに TSH を投 与した際の甲状腺 $($ H.E. $\times 200)$

小型濾胞经著るしく增加し，濾胞上皮虻肥大增 殖を来たし，濾胞内のコロイドル減少している。

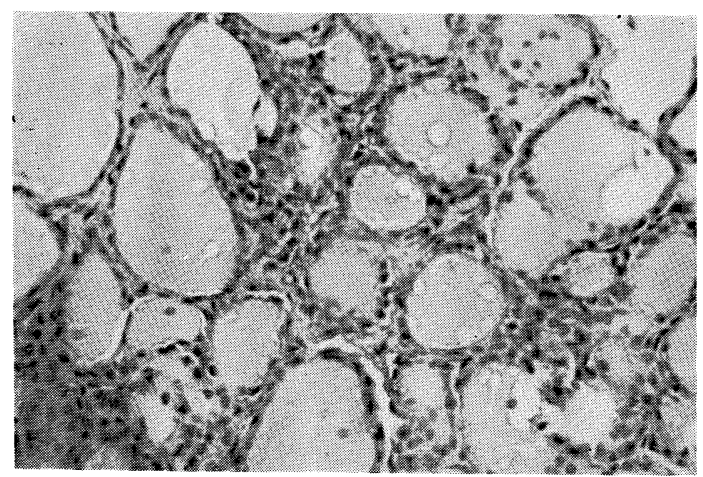

(11)卡勢雄ラツトに E.P. ホルテン (estradiol denz. $50 \gamma$ : progesterone $2.5 \mathrm{mg}$ ) 在前処置後 TSH を投与した際の甲状腺 $($ H.E. $\times 200)$

対照(9)比し滤胞上皮の厚径良稍々その大きさ を減し，滤胞直径主増大の傾向を示し，一部の 濾胞にに周辺部空胞が認められる。

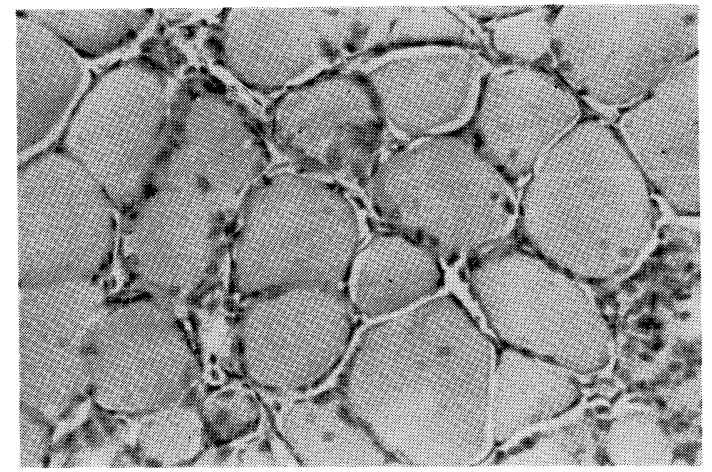

(8)下垂体剔出倠ラツトと estradiol benzoate $200 \gamma$ 在投与した際のH状腺 (H.E. × 100) 対照 $(7)$ と著変を認めない。

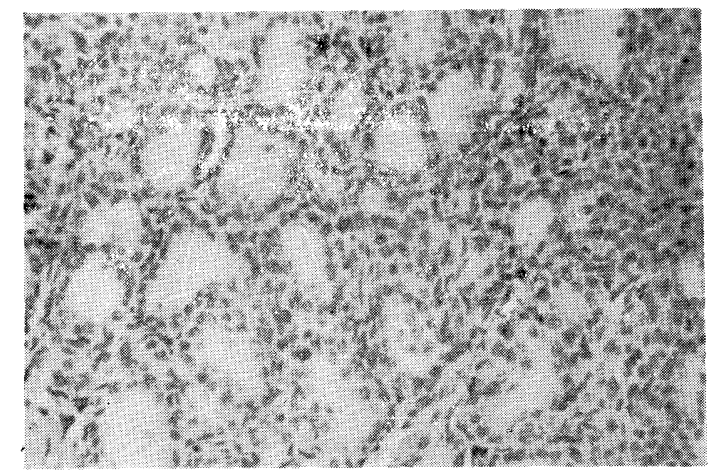

(10)去勢雄ラツトに estradiol benzoate $5 \gamma$ を前処 置後 'TSH 在投与した際の甲状腺 $($ H.E. $\times 200)$ 一部濾胞上皮に心乳嘴状増殖がみられ，ために 滤胞腔㹸消失している。

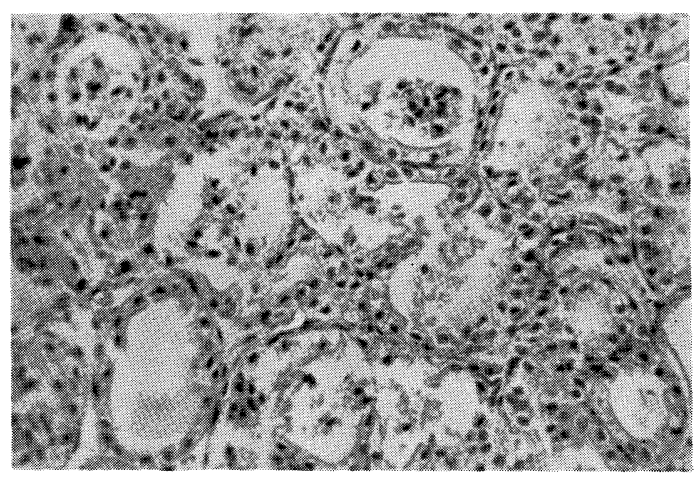

(12)去勢雄ラットに testosterone propionate $25 \mathrm{mg}$ 在前処置後 TSH を投与した際の甲状腺 (H.E. $\times 200$ )

滤胞上皮心著るしく肥大し一部乳嘴状増殖を示 し，濾胞腔内に心上皮細胞の剝離を認める。 
23) Money, W.L., L.Kraintz, J. Fager, L. Kirschner, R.W. Rawson : Endocrinol., 48 : 682, 1951.

高折忠太 : 日本内分泌学会雑誌，30:543，1954. 1109, 1951. (Ber., $154: 242,1952 \sim 1953$.)

1941.

27) Zingg, W. \& W.F. Perry :

: Endocrinol., 58 : 327, 1956.

29) Feldman, J.D. : Endocrinol., $59: 289,1956$.

31) Alexiv, M. : Arch. f. Gynäk., $169: 432,1939$.

25) Vlyssides, Z. et al. : C.r. Soc. Biol., 145 :

H. : Arch. f. Gynäk., 119 : 459, 1923.

31) Alexiu, M. : Arch. f. Gynäk.,
usia : Klin. Wschr., 15 : 1001, 1936.

33) Pincus, $G . \&$ De Amiliba, E., M.M. Mendizabal, J. Botella-Liusia : Klin
W.H. Pearlman : Vitamins \& Hormones, $1: 294,1943$.

34) Albert, A. : Endocrinol., $50: 324,1952$.

35) Grant, K.B. : Endocrinol., $56: 607,1955$.

36) Leathem, J.H. : Anat. Rec., $109: 318,1951$.

37) Burris, M.J., R. Bogart, H. Krueger : Proc. Soc. Exp. Biol. \& Med., 84 : 181, 1953.

38) Castellari, L. : Arch. Maragliano Pat., 7 : 79, 1952. (Excerpta 7 : 12, 1953.)

39) Gassner. F.X., H.W. Earrett, R.G. Gustavson : Trans. Am. Ass. Study Goiter, 156, 1947. ((22) より引用) 40) 小川栄—, 板 垣仙次郎：日本薬理学会雑誌，50:199，1954.

41) Paschkis, K.E., A. Cantarow, W.C. Pecicock: Proc. Soc. Exp. Biol. \& Med., 68 : 485, 1948.

42) Schilling, W. \& L. Laqueur : Endocrinol., 29 : 103, 1941.

43) Brauner, F. et al. : Arch. internat. Pharmacodyn., 81 : 369, 1950.

44) 淞村

景雄：産科婦人科紀要，27:153，1944.

45) 佐藤弘：日本産科婦人科学会雑誌，9:115，1957. 46) 林義夫, 宮下舜一：北海道産科婦人科学会雑誌，6:44，1955.

47) Dogliotti, V. : Ann. di ostet. e ginec., $56: 547$, 1934. ((12) 九り引用)

48) Proto, M. : Policlinico, $41: 460,1934$. ((12) より引用)

49) Emge, L.A. \& G.L. Lqqueur : Endocrinol., 29 : 96, 1941.

50) Starr, P. \& C. Bruner : Proc. Soc. Exp. Biol. \& Med., $33: 465,1935 . \quad 51)$ Pincus, G. \& N. Werthessen : Am. J. Physiol., $103: 631,1933$.

52) Tagliaferro, P. : Folia Gynaec., $30: 597,1933$.

53) Freucienterger. C.B. \& F.W. Clausen : Anat. Rec., 68 : 133, 1937. 54) Freudenberger, C.B. \& F.W. Clausen : Anat. Rec., 69 : 171, 1937. 55) Wolrerink, L.F. et al. : Fed. Proc., 9 : 138, 1950.

56) Lerman, J. : Progress in Gynecology, $11: 253,1950$.

57) Andersen, D.H. : J. Physiol., 83 : 15, 1934. Leonard, S. L., R.K. Meyer, F.L. Hisaw : Endocrinol., 15 : 17, 1931. 59) Heyl, J.G., S.E. De;ough, R. Kooy : Act. brev. Neerl. physiol., 4 : 126, 1934. ((49) るり引用)

60) Karp, L. \& B. Kostkiewicz : Klin. Wschr., $13: 489,1934 . \quad 61)$ Frank, S. : Compt. rend. Soc. Biol., $125: 573$, 1937. ((49) \&り 引用) 62) Kreitmar, H. \& W. Sieckman : Klin. Wschr., $18: 156,1939 . \quad$ 63) Gardrer, J.H. : Proc. Soc. Exp. Biol. \& Med., $72: 306,1949$.

64) Desclin, L. \& A.M. Ermans : Ann. Endocrinol., $12:$ 238, $1951 . \quad$ 65) Arnold, O.H. et al. : Arch. f. Exp. Path. u. Pharmak., $191: 192,1938$. 66) Müller, J.H. \& H. Aeppli : Gynecologia, $128: 422,1949 . \quad 67)$ Leiby, G.M. : Proc. Soc. Exp. Biol. \& Med., 31 : 15, 1933.

68) Soliman, F.A. \& E.P. Reineke : Am. J. Physiol., $183: 63,1955$.

69）鈴木文司：日本不妊学会雑誌，2:27，1957。

70) Conner, M.H. \& C.S. Shaffrer : Endocrinol., $55:$ 45, 1954. 71）土肥定：産婦人科の進歩，10:230，1958. 72) Brown-Grant, K.: J. Physiol., 127 : 390, $1955 . \quad$ 73) 小山良修 : Jap. J. Med. S.IV Pharmacol., 5 :

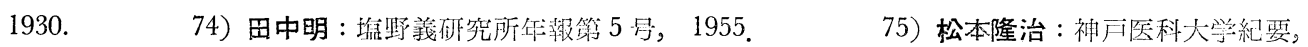
$15: 328$, 1959. 76) Aron, M. \& J. Benoit : Compt. Rend. Soc. Biol., 109 : 923, 1932. ((49)上り引肘) 77) Loeser, A. : Klin. Wschr., $13: 766,1934 . \quad$ 78) Loeser, A. : Klin. Wschr., $14: 4,1935$. Desclin, L. \& A.M. Ermans : Compt. Rend. Soc. Biol., $144: 1277,1950$. (Chem. Abst., 45 : 5265,1951.) 80) Turner, C.W. \& P.T. Cupps : Endocrinol., $26: 1042,1940 . \quad$ 81) Leblond, C.P. et al. : Proc. So:. Exp. Biol. N.Y., 51 : 159, 1942. ((72) Łり用周) 82) 山本淸 : 内分泌機能の协四。1956. 83) 木戸孝治：日本内分泌学会雑瓶，34:274，1958. 